\title{
Microbial enhanced oil recovery: interfacial tension and biosurfactant- bacteria growth
}

\author{
Wira Putra ${ }^{1}\left(\right.$ Farizal Hakiki $^{2}$ (]
}

Received: 3 February 2019 / Accepted: 21 February 2019 / Published online: 5 March 2019

(c) The Author(s) 2019

\begin{abstract}
Microbial enhanced oil recovery (MEOR) is a method that utilises bacteria or bioproducts to increase oil recovery at the tertiary stage. Clostridium sp. produces biosurfactant that alters rock-fluid properties and increases oil detachment. The interaction between bacteria and surfactant is interesting relation to study. We revisit and develop models for biosurfactantproducing bacteria's growth and the interfacial tension (IFT) response. The biosurfactant-producing bacteria growth model (BBG model) mimics the predator-prey interaction and the IFT response model derived from analogy. Both models form an integrated model called coupled-simultaneous model. We deliver the suitability of these models to experimental datasets by conducting parameter estimation. The decreased number of parameter in BBG model is with the help of rate estimation model. It estimates the bacteria growth rate and biosurfactant production rate. This research introduces a graphical method to narrow parameters initial guess in the IFT model. The method comes with a proposed index to compare surfactant performance called as surfactant performance index (SPI). The paper exposes the logic of each parameter, physics behind the models, and addresses the mathematical artefacts. The significant findings are valuable to anticipate bacterial performance for MEOR.
\end{abstract}

Keywords MEOR $\cdot$ Bacteria growth $\cdot$ Biosurfactant $\cdot$ Interfacial tension $\cdot$ Surfactant performance index $\cdot$ Predator-prey

\section{Introduction}

\section{MEOR mechanisms and aims}

Microbial enhanced oil recovery (MEOR) is a method that utilises bacteria or bioproducts to alter rock-fluid properties. It is suggested in 1926 (Beckmann 1926) and systematically investigated in 1947 (ZoBell 1947a, b). A detailed literature study has summarised its recent developments and worldwide applications (Patel et al. 2015). Table 1 reports the bacteria bioproducts associated with possible MEOR

Authors were performing this research during January-August 2015 while they were still affiliated with Institut Teknologi Bandung (ITB), Indonesia.

Farizal Hakiki

farizal.hakiki@kaust.edu.sa

1 PT Bhinneka Mentari Dimensi, ORCA Research and Development Team, Tangerang 15345, Indonesia

2 King Abdullah University of Science and Technology (KAUST), Ali I. Al-Naimi Petroleum Engineering Research Center (ANPERC), Thuwal 23955, Saudi Arabia mechanisms. MEOR mechanism adapts the chemical-based EOR (Hartono et al. 2017), however, it corresponds to a combined distinct-EOR because microbes could produce biosurfactant, biopolymer, and gas simultaneously. There are other mechanisms such as the consumption of hydrocarbon and degradation of heavy long-carbon-chains into light and short (Sen 2008; Gudina et al. 2012; Cheng et al. 2014; Patel et al. 2015; Cai et al. 2015; Varjani and Upasani 2016; Zhao et al. 2018; Iraji and Ayatollahi 2018).

There are several possible schemes in MEOR: (i) injecting exogenous bacteria, (ii) injecting active indigenous bacteria, (iii) supplying the nutrients only, (iv) combination of scheme i-iii. The common approach is to conduct huff-andpuff. Microbial huff-and-puff involves nutrient and microbes injection into production wells, soak them for a period of time, and then continue to produce the oil. Therefore, understanding how bacteria behave becomes essential, from the growth, bioproducts formation, and the effect on rock-fluid properties.

Time constraint is critical when the bacteria or bioproducts make an alteration in the reservoir because it guides the huffand-puff shutting and injection duration scheme. Interfacial 
Table 1 Role of microbial bioproducts in EOR

\begin{tabular}{|c|c|c|}
\hline Microbial products & Proposed mechanisms & Related papers (experimental/field results) \\
\hline Gases $\left(\mathrm{H}_{2}, \mathrm{~N}_{2}, \mathrm{CH}_{4}, \mathrm{CO}_{2}\right)$ & $\begin{array}{l}\text { Displace immobile and sweep oil in place } \\
\text { Reservoir repressurization } \\
\text { Oil swelling or viscosity reduction } \\
\text { Carbonate rocks solubilization by } \mathrm{CO}_{2}^{\mathrm{c}, \mathrm{d}} \\
\text { Local stratal pressure stabilization }^{\mathrm{c}}\end{array}$ & $\begin{array}{l}\text { Purwasena et al. (2014), Zheng et al. (2012), Gudina et al. } \\
\text { (2012), Xu and Lu (2011), Sugai et al. (2010), Bao et al. } \\
\text { (2009), Kowalewski et al. (2006) }\end{array}$ \\
\hline Organic Acids & $\begin{array}{l}\text { Permeability and porosity improvement }{ }^{\mathrm{a}, \mathrm{b}, \mathrm{c}, \mathrm{d}} \\
\text { Reaction with calcareous rocks } \\
\mathrm{CO}_{2} \text { production }^{\mathrm{a}, \mathrm{d}, \mathrm{d}}\end{array}$ & $\begin{array}{l}\text { Harner et al. (2011), Sen (2008), Lazar et al. (2007), Adkins } \\
\text { et al. (1992), Udegbunam et al. (1991) }\end{array}$ \\
\hline Solvents & $\begin{array}{l}\text { Dissolve in oil, reduce viscosity }{ }^{\mathrm{a}, \mathrm{b}} \\
\text { Dissolve in oil, remove heavy oil from pore throat }{ }^{\mathrm{a}, \mathrm{c}, \mathrm{d}} \\
\text { Reduce IFT, and promote emulsification } \\
\text { a,b }\end{array}$ & Pinilla et al. (2011), Bryant (1990), Bryant (1987) \\
\hline Biosurfactants & $\begin{array}{l}\text { Reduce IFT, and promote emulsification } \\
\text { Wettability alteration }^{\mathrm{a}, \mathrm{b}}\end{array}$ & $\begin{array}{l}\text { Fernandes et al. (2016); Zheng et al. (2012), Ghojavand et al. } \\
\text { (2012), Gudina et al. (2012), Sen (2008), Pornsunthorn- } \\
\text { tawee et al. (2008), Joshi et al. (2008), Lazar et al. (2007) }\end{array}$ \\
\hline Biopolymers & $\begin{array}{l}\text { Selective plugging }{ }^{\mathrm{a}, \mathrm{b}, \mathrm{c}, \mathrm{d}} \\
\text { Control of water mobility } \mathrm{a}, \mathrm{b}, \mathrm{c}, \mathrm{d}\end{array}$ & $\begin{array}{l}\text { Tianyuan et al. (2018), Lal et al. (2009), Pornsunthorntawee } \\
\text { et al. (2008), Sen (2008), Healy et al. (1996), Raiders et al. } \\
\text { (1989), Bryant (1987) }\end{array}$ \\
\hline Biomass (Microbial cells) & $\begin{array}{l}\text { Physical oil displacement }^{\mathrm{a}} \\
\text { Wettability alteration }^{\mathrm{a}, \mathrm{c}} \\
\text { Degradation of oil }^{\mathrm{a}, \mathrm{d}} \\
\text { Selective and nonselective plugging } \\
\text { Oil viscosity and pour point alteration } \\
\text { Oil desulfurization } \\
\text { a,d } \\
\text { Oil emulsification }^{\mathrm{c}, \mathrm{d}} \\
\text { Oil de-emulsification }^{\mathrm{c}}\end{array}$ & $\begin{array}{l}\text { Halim (2015), Zheng et al. (2012), Okeke and Lane (2012); } \\
\text { Ohms et al. (2009), Sen (2008), Lazar et al. (2007), Yaki- } \\
\text { mov et al. (1997), Bryant (1987) }\end{array}$ \\
\hline
\end{tabular}

Compiled from ${ }^{a}$ Lazar et al. (2007); ${ }^{b}$ McInerney et al. (2005); ${ }^{\mathrm{c} B e l y a e v}$ et al. (2004); ${ }^{\mathrm{d} J a n s h e k a r ~(1985) ~}$

tension (IFT) is also important to represent the rock-fluid and oil-brine properties. A lower IFT contributes to wettability alteration, to higher oil-detachment from rock surface, and to influence recovery (Jadhunandan and Morrow 1995; Hakiki et al. 2015). Unfortunately, a wettability alteration by biosurfactant could be significant at freshwater but not in brine (Veshareh et al. 2018). A contributing lower IFT to increase capillary number is proven to obtain a less residual-oil saturation (Hakiki et al. 2017).

This research aims to develop an integrated model of biosurfactant-producing bacteria growth and its IFT response. The model focuses on Clostridium sp. as the biosurfactant producer. The results can provide a better understanding of bacteria growth and the IFT with respect to time. This information can help optimising MEOR operation.

\section{Biosurfactant-producing bacteria growth model}

Growth model research has been going for a long time even from 190 years ago. The subject may be animate such as human population, animals, microorganisms, and trees in the forest. It also includes an abstract object such as geologic, business, and economic growth.
The model may describe microbial growth under constant temperature or it may be temperature dependent. The basic form of model which describes microbial growth under constant temperature is called primary model (Swinnen et al. 2004; Corradini et al. 2005; Juneja et al. 2007, 2009; Gospavic et al. 2008; Theys et al. 2008; Huang 2013). The two most widely used growth models are the Baranyi and Gompertz models (Buchanan et al. 1997). Most of the growth model is empirical, usually sigmoid model, but some are more mechanistic such as the application of kinetic modelling (Altiok et al. 2006; Yang et al. 2011; Gahlawat and Srivastava 2013). Table 2 summarises the existing growth models.

It is common to include a temperature-dependent model complemented with the growth model for temperature-dependent growth model. There are many studies on microbial growth with the temperature-dependent model (Zwietering et al. 1994; Daughtry et al. 1997; Bovill et al. 2000; Fujikawa et al. 2004; Corradini et al. 2005; Dominguez and Schaffner 2007; Juneja et al. 2007, 2009; Gospavic et al. 2008; Salih et al. 2012). Other alternative may include salinity, $\mathrm{pH}$, temperature, and nutrient concentration into the model (Hosseininoosheri et al. 2016). 
Table 2 Summary of growth models

\begin{tabular}{|c|c|c|c|c|}
\hline Growth model & Author(s) & Model & $\begin{array}{l}\text { \# Param- } \\
\text { eters }\end{array}$ & Additional informations \\
\hline Linear & - & $P\left(t ; P_{0}, \alpha\right)=P_{0}+\alpha t$ & 2 & \\
\hline Logarithmic reciprocal & - & $P(t ; \alpha, \beta)=\exp \left(\alpha-\frac{\beta}{t}\right)$ & 2 & \\
\hline First-order kinetics & - & $P\left(t ; P_{0}, \alpha\right)=P_{0} \exp (-\alpha t)$ & 2 & \\
\hline Negative exponential & - & $P\left(t ; P_{\infty}, \alpha\right)=P_{\infty}[1-\exp (-\alpha t)]$ & 2 & \\
\hline Log logistic & - & $P\left(t ; P_{\infty}, \alpha, \beta\right)=\frac{P_{\infty}}{1+\alpha \exp [-\beta \ln (t)]}$ & 3 & $\begin{array}{l}\text { Popular in fitting dose- } \\
\text { response curves }\end{array}$ \\
\hline Hossfeld & Hossfeld (1822) & $P\left(t ; P_{\infty}, \alpha, \beta\right)=\frac{P_{\infty}}{1+\alpha t^{-\beta}}$ & 3 & \\
\hline Gompertz & Gompertz (1825) & $P\left(t ; P_{\infty}, \alpha, \beta\right)=P_{\infty} \exp [-\alpha \exp (-\beta t)]$ & 3 & $\begin{array}{l}\text { Commonly used and } \\
\text { modified empirical } \\
\text { model }\end{array}$ \\
\hline Logistic & Verhulst (1838) & $P\left(t ; P_{\infty}, \alpha, \beta\right)=\frac{P_{\infty}}{1+\alpha \exp (-\beta t)}$ & 3 & \\
\hline Lotka-Volterra & Lotka (1910) & $\frac{\mathrm{d} x}{\mathrm{~d} t}=\alpha x-\beta x y ; \frac{\mathrm{d} y}{\mathrm{~d} t}=-\gamma y+\delta x y$ & - & $\begin{array}{l}\text { Also known as predator- } \\
\text { prey model }\end{array}$ \\
\hline Levakovic I & Levakovic (1935) & $P\left(t ; P_{\infty}, \alpha, \beta, \gamma\right)=\frac{P_{\infty}}{\left(1+\alpha t^{-\beta}\right)^{\gamma}}$ & 4 & \\
\hline Levakovic III & Levakovic (1935) & $P\left(t ; P_{\infty}, \alpha, \beta\right)=\frac{P_{\infty}}{\left(1+\alpha t^{-2}\right)^{\beta}}$ & 3 & \\
\hline \multirow[t]{2}{*}{ Brody } & Brody (1945) & $\begin{array}{l}\text { Phase } 1 \text { (expansionary phase) } \\
P(t ; \alpha, \gamma)=\alpha \exp (\gamma t)\end{array}$ & 2 & \\
\hline & & $\begin{array}{l}\text { Phase } 2 \text { (declining phase) } \\
P\left(t ; P_{\infty}, \beta, \gamma\right)=P_{\infty}[1-\beta \exp (-\gamma t)]\end{array}$ & 3 & \\
\hline Weibull & Weibull (1951) & $P\left(t ; P_{\infty}, \alpha, \beta, \gamma\right)=P_{\infty}-\alpha \exp \left(-\beta t^{\gamma}\right)$ & 4 & \\
\hline von Bertalanffy & $\begin{array}{l}\text { von Bertalanffy } \\
\text { (1957) }\end{array}$ & $\frac{\mathrm{d} P}{\mathrm{~d} t}=\alpha P^{\gamma}-\beta P$ & - & \\
\hline Lundqvist-Korf & $\begin{array}{l}\text { Korf (1939), Lun- } \\
\text { dqvist (1957) }\end{array}$ & $P\left(t ; P_{\infty}, \alpha, \beta\right)=P_{\infty} \exp \left(-\alpha t^{-\beta}\right)$ & 3 & \\
\hline Janoschek & Janoschek (1957) & $P\left(t ;, P_{\infty}, \alpha, \beta, \gamma\right)=P_{\infty}\left[1-\alpha \exp \left(-\beta t^{\gamma}\right)\right]$ & 4 & \\
\hline Richards & Richards (1959) & $P\left(t ; P_{\infty}, \alpha, \beta, \gamma\right)=\frac{P_{\infty}}{\{1+\alpha \exp [-\beta(t-\gamma)]\}^{1 / \alpha}}$ & 4 & \\
\hline Sloboda & Sloboda (1971) & $P\left(t ; P_{\infty}, \alpha, \beta, \gamma\right)=P_{\infty} \exp \left[-\alpha \exp \left(-\beta t^{\gamma}\right)\right]$ & 4 & \\
\hline Schnute & Schnute (1981) & $\frac{\mathrm{d} P}{\mathrm{~d} t}=\alpha P ; \frac{\mathrm{d} \alpha}{\mathrm{d} t}=-\alpha(\beta \alpha+\gamma)$ & - & $\begin{array}{l}\text { Models the accelerated } \\
\text { growth of fish popula- } \\
\text { tion }\end{array}$ \\
\hline Yoshida I & Yoshida (1981) & $P\left(t ; P_{\infty}, \alpha, \beta\right)=\frac{P_{\infty}}{1+\alpha t^{-\beta}}+\beta$ & 3 & \\
\hline Modified Janoschek & Sager (1984) & $P\left(t ; P_{\infty}, P_{0}, \alpha, \beta\right)=P_{\infty}-\left(P_{\infty}-P_{0}\right) \exp \left(-\alpha t^{\beta}\right)$ & 4 & \\
\hline Stannard & Stannard et al. (1985) & $P\left(t ; P_{\infty}, \alpha, \beta, \gamma\right)=\frac{P_{\infty}}{\left[1+\exp \left(-\frac{\alpha+\beta t}{\gamma}\right)\right]^{\gamma}}$ & 4 & \\
\hline Expolinear & $\begin{array}{l}\text { Goudriaan and Mon- } \\
\text { teith (1990) }\end{array}$ & $P(t ; \alpha, \beta, \gamma)=\frac{\alpha}{\beta} \ln \{1+\exp [\beta(t-\gamma)]\}$ & 3 & \\
\hline McDill-Amateis & $\begin{array}{l}\text { McDill and Amateis } \\
\text { (1992) }\end{array}$ & $P\left(A ; P_{\infty}, P_{0}, A_{0}, \alpha\right)=\frac{P_{\infty}}{1-\left(1-\frac{P_{\infty}}{P_{0}}\right)\left(\frac{A_{0}}{A}\right)^{\alpha}}$ & 4 & $\begin{array}{l}\text { Growth model derived } \\
\text { from dimensional } \\
\text { analysis for pine forest } \\
\text { site quality observed } \\
\text { from the highest growth }\end{array}$ \\
\hline Baranyi & Baranyi et al. (1993) & $\frac{\mathrm{d} P}{\mathrm{~d} t}=\frac{\alpha}{1+\exp (-q)}\left\{1-\exp \left[\beta\left(P-P_{\infty}\right)\right]\right\} ; \frac{\mathrm{d} q}{\mathrm{~d} t}=\alpha$ & - & $\begin{array}{l}\text { Kinetically based growth } \\
\text { model }\end{array}$ \\
\hline Symmetrical expolinear & $\begin{array}{l}\text { Goudriaan and van } \\
\text { Laar (1994) }\end{array}$ & $P\left(t ; P_{\infty}, \alpha, \beta, \gamma\right)=\frac{\alpha}{\beta} \ln \left\{\frac{1+\exp [\beta(t-\gamma)]}{1+\exp \left[\beta\left(t-\gamma-\frac{P_{\infty}}{\alpha}\right)\right]}\right\}$ & 4 & \\
\hline Baranyi & $\begin{array}{l}\text { Baranyi and Roberts } \\
\text { (1994) }\end{array}$ & $\begin{array}{l}P\left(t ; P_{0}, P_{\infty}, \alpha, \beta, \gamma\right)=P_{0}+\alpha A(t)-\ln \left\{1+\frac{\exp [\alpha A(t)]-1}{\exp \left(P_{\infty}-P_{0}\right)}\right\} \\
\text { Where } \\
A(t)=t+\frac{1}{\beta} \ln \left(\mathrm{e}^{-\beta t}+\mathrm{e}^{-\gamma}-\mathrm{e}^{-\beta t-\gamma}\right)\end{array}$ & 5 & \\
\hline
\end{tabular}


Table 2 (continued)

\begin{tabular}{|c|c|c|c|c|}
\hline Growth model & Author(s) & Model & $\begin{array}{l}\text { \# Param- } \\
\text { eters }\end{array}$ & Additional informations \\
\hline Beta & $\begin{array}{l}\text { Yin et al. (1995, } \\
\text { 2003) }\end{array}$ & $P\left(t ; P_{\infty}, \alpha, \beta, \gamma\right)=P_{\infty}\left(1+\frac{\alpha-t}{\alpha-\beta}\right)\left(\frac{t}{\alpha}\right)^{\frac{\alpha}{\alpha-\beta}}$ & 4 & \\
\hline Birch & Birch (1999) & $\frac{\mathrm{d} P}{\mathrm{~d} t}=\frac{\alpha P(\beta-P)}{\beta-P+\gamma P}$ & - & \\
\hline Fujikawa & Fujikawa et al. (2004) & $\frac{d P}{d t}=\alpha P\left(1-\frac{P}{P_{\infty}}\right)\left(1-\frac{P_{\min }}{P}\right)^{\beta}$ & - & $\begin{array}{l}\text { A model based on } \\
\text { logistic model to model } \\
\text { Escherichia coli } \text { growth }\end{array}$ \\
\hline Gougouli & Gougouli et al. (2008) & $\begin{array}{l}\frac{\mathrm{d} P}{\mathrm{~d} t}=\left[\alpha\left(T-T_{\min }\right)\right]^{2}\left(\frac{q}{q+1}\right)\left(1-\frac{P}{P_{\infty}}\right) P \\
\text { where } \\
\frac{\mathrm{d} q}{\mathrm{~d} t}=\left[\alpha\left(T-T_{\text {min }}\right)\right]^{2} q\end{array}$ & - & \\
\hline Huang & Huang (2008) & $\begin{array}{l}P\left(t ; P_{0}, P_{\infty}, \alpha, \beta, \gamma\right)=P_{0}+P_{\infty}-\ln \left\{\exp \left(P_{0}\right)\right. \\
\left.\quad+\left[\exp \left(P_{\infty}\right)-\exp \left(P_{0}\right)\right]\right\} \exp \left[-\beta \exp \left(P_{\infty}\right) B(t)\right] \\
\text { where } \\
B(t)=t+\frac{1}{\alpha} \ln \frac{1+\exp \{-\alpha(t-\gamma)\}}{1+\exp (\alpha \gamma)}\end{array}$ & 5 & $\begin{array}{l}\text { Models isothermal } \\
\text { growth kinetics of } \\
\text { Listeria monocytogenes } \\
\text { in broth and beef frank- } \\
\text { furters }\end{array}$ \\
\hline Halim & Halim et al. (2009) & $\begin{array}{l}\frac{\mathrm{d} P}{\mathrm{~d} t}=\alpha_{1} P-\frac{\alpha_{1}}{\beta} P^{2}-\gamma_{2} P S \\
\frac{\mathrm{d} S}{\mathrm{~d} t}=\alpha_{2} P-\gamma_{2} P S\end{array}$ & - & $\begin{array}{l}\text { Models biosurfactant- } \\
\text { producing bacteria }\end{array}$ \\
\hline Koya-Goshu & $\begin{array}{l}\text { Koya and Goshu } \\
\text { (2013) }\end{array}$ & $\begin{array}{l}P\left(t ; \alpha, \alpha_{L}, \alpha_{\mu}, \beta, \gamma, \delta, \mu, \nu\right)=\alpha_{L}+\left(\alpha-\alpha_{L}\right) \\
\quad\left\{1-B \exp \left[-\beta\left(\frac{t-\mu}{\delta}\right)^{\nu}\right]\right\}^{\gamma} \\
B=1-\left(\frac{\alpha_{\mu}-\alpha_{L}}{\alpha-\alpha_{L}}\right)^{1 / \gamma}\end{array}$ & 8 & $\begin{array}{l}\text { Generalisation of com- } \\
\text { monly used growth } \\
\text { models. Koya-Goshu } \\
\text { model has the most } \\
\text { parameters to be esti- } \\
\text { mated compared to all } \\
\text { the previous models }\end{array}$ \\
\hline
\end{tabular}

Growth model of biosurfactant-producing bacteria may couple logistic-growth and modify predator-prey model (see Eq. 1, Halim et al. 2009).

$\frac{\mathrm{d} P}{\mathrm{~d} t}=\mu_{1} P-\frac{\mu_{1}}{K_{0}} P^{2}-\gamma P S$

$\frac{\mathrm{d} S}{\mathrm{~d} t}=\mu_{2} P-\delta P S$

$P$ is the number of bacteria in base-10 logarithm for each cell $/ \mathrm{mL}, S$ is biosurfactant concentration $(\mathrm{g} / \mathrm{L}), \mu_{1}$ is bacteria growth rate $\left(\mathrm{h}^{-1}\right), \mu_{2}$ is biosurfactant production rate $(\mathrm{mg} /$ cell $/ \mathrm{h}), K_{0}$ is carrying capacity (cell/mL), $\gamma$ is toxicity constant $(\mathrm{L} / \mathrm{g} / \mathrm{h})$, and $\delta$ is predation factor $(1 / \mathrm{h})$. Equation (1) assumes that there is a significant reduction of bacteria due to environmental adjustment at the initial stage (Halim et al. 2009). The initial condition is at the next time step of the data i.e. after reduction. The reduction is normal when bacteria is exposed to a high pressure condition (Pruitt and Kamau 1993). There are mismatches and confusing physical units in Eq. 1 that this paper will address.

\section{Interfacial tension response model}

Biosurfactant produced by bacteria decreases the tension at the oil-water interface, which eases oil to detach from the rock. The model for IFT response due to biosurfactant concentration is proposed as in Eq. (2) (Hakiki 2014).

$-\frac{\mathrm{d} \sigma}{\mathrm{d} S}=\frac{\sigma_{0}-\sigma}{S}-\eta\left(\sigma_{0}-\sigma\right)$.

$\sigma$ is IFT $(\mathrm{mN} / \mathrm{m}), \sigma_{0}$ is initial IFT $(\mathrm{mN} / \mathrm{m}), S$ is biosurfactant concentration $(\mathrm{g} / \mathrm{L})$, and $\eta$ is a damping constant $(\mathrm{L} / \mathrm{g})$. The minus sign represents IFT reduction with respect to biosurfactant concentration. The reduction rate decreases as the concentration gets higher. Solution of Eq. (2) through variable separation is Eq. (3)

$\sigma=\sigma_{0}[1-C S \exp (-\eta S)]$,

where $C$ and $\eta$ are constants (L/g). IFT response model is useful in determining critical micelle concentration (CMC). 
Table 3 List of the experimental data

\begin{tabular}{|c|c|c|c|c|c|}
\hline Name/Literature & Used for & Data & Code & Bacteria/consortium & Medium \\
\hline \multirow[t]{3}{*}{ DATA1/Primeia (2008) } & \multirow[t]{3}{*}{$\begin{array}{l}\text { Testing BBG model } \\
\text { With- and without-REM }\end{array}$} & \multirow[t]{3}{*}{ Three data of $P$ and $S$ vs $t$} & $1 \mathrm{~A}$ & Clostridium sp. & $\begin{array}{l}\text { SMSS medium }+0.01 \% \\
\text { (m/v) NPK }+20 \% \\
(\mathrm{v} / \mathrm{v}) \text { crude oil }\end{array}$ \\
\hline & & & 1B & Clostridium sp. & $\begin{array}{l}\text { SMSS medium }+0.03 \% \\
\text { (m/v) NPK }+20 \% \\
\text { (v/v) crude oil }\end{array}$ \\
\hline & & & $1 \mathrm{C}$ & Clostridium sp. & $\begin{array}{l}\text { SMSS medium }+0.05 \% \\
\text { (m/v) NPK }+20 \% \\
\text { (v/v) crude oil }\end{array}$ \\
\hline \multirow[t]{6}{*}{ DATA2/Bitticaca (2009) } & \multirow[t]{6}{*}{ Testing IFT model } & \multirow[t]{4}{*}{$\begin{array}{l}\text { Four data of biosurfactant } \\
\text { IFT }\end{array}$} & $2 \mathrm{~A}$ & $\begin{array}{l}\text { 1:1 Bacillus sp. and Bacil- } \\
\text { lus polymyxa }\end{array}$ & \multirow{4}{*}{$\begin{array}{l}\text { SMSS medium }+0.01 \% \\
\text { (m/v) NPK }+20 \% \\
\text { (v/v) crude oil }\end{array}$} \\
\hline & & & $2 \mathrm{~B}$ & $\begin{array}{l}\text { 1:2 Bacillus sp. and Bacil- } \\
\text { lus polymyxa }\end{array}$ & \\
\hline & & & $2 \mathrm{C}$ & $\begin{array}{l}\text { 2:1 Bacillus sp. and Bacil- } \\
\text { lus polymyxa }\end{array}$ & \\
\hline & & & $2 \mathrm{D}$ & Bacillus polymyxa & \\
\hline & & \multirow{2}{*}{$\begin{array}{l}\text { Two data of synthetic } \\
\text { surfactant IFT }\end{array}$} & $2 \mathrm{E}^{*}$ & - & - \\
\hline & & & $2 \mathrm{~F}^{*}$ & - & - \\
\hline DATA3/Primeia (2008) & Testing CSM & $\begin{array}{l}\text { One complete data of } P, S \text {, } \\
\text { and } \sigma \text { vs } t\end{array}$ & - & Clostridium sp. & $\begin{array}{l}\text { SMSS medium }+0.05 \% \\
(\mathrm{~m} / \mathrm{v}) \mathrm{NPK}+20 \% \\
(\mathrm{v} / \mathrm{v}) \text { crude oil }\end{array}$ \\
\hline
\end{tabular}

SMSS stone mineral salt solution

\section{Methods}

\section{Experimental data}

Table 3 lists the detailed experimental data, usage in this research, bacteria name or type, medium of cultivation, and the supplied nutrient. Detailed composition through GCMS analysis of Handil Field crude oil is available in the literature (Fulazzaky et al. 2015). All data have incubation temperature of $50-55{ }^{\circ} \mathrm{C}$. The experimental data used stone mineral salt solution (SMSS) as the growth substrate in a batch system under anaerobic condition.

DATA 1: Three experimental datasets of bacteria growth and biosurfactant concentration are from indigenous bacteria in Handil Field, East Kalimantan, Indonesia (Primeia 2008). The isolated cultures of bacteria from this field are Flavimonas oryzihabitants, Amphibacillus xylanus, Bacillus polymyxa, Bacillus macerans, and Clostridium sp. (Purwasena 2006; Primeia 2008). We only use the data of Clostridium sp. growth and biosurfactant concentration to validate biosurfactant-producing bacteria growth model.

DATA 2: The literature provides six experimental datasets of biosurfactant and commercial surfactant, and IFT (Bitticaca 2009). The data are also from Handil Field in East Kaliman$\tan$, Indonesia. Four of them are biosurfactant concentration and IFT response data of Bacillus sp. and Bacillus polymyxa consortium. Two others are the surfactant and IFT response of commercial synthetic surfactant coded S7A and S13A*. Those data benefit for the validation of IFT response model. A latter study reveals a similar trend of producing biosurfactant from Bacillus sp. at early $30 \mathrm{~h}$ cultivation (Heryani and Putra 2017).

DATA 3: The data consists of one experimental dataset of Clostridium sp. growth, biosurfactant concentration, and IFT (Primeia 2008). The dataset are useful to evaluate whether or not the proposed models (biosurfactant-producing bacteria growth model and IFT response model) can be coupled and solved simultaneously.

\section{Parameter estimation}

The main problem in solving the proposed model is to fit the simultaneous differential equation solution with the data. We deploy the sum of residual sum of squares (SRSS) as the objective of optimisation. Equation (4) shows the objective equation

$\min _{p} \varepsilon_{\mathrm{tot}}=\min _{p}\left[\sum_{i=1}^{m}\left(\sum_{j=1}^{n} \varepsilon_{j}^{2}\right)_{i}\right]$,

where $p$ are parameters to be estimated, $\varepsilon_{\text {tot }}$ is the SRSS, which sums up each $i$-th residual sum of squares (RSS) out of $m$ number of equation, and $\varepsilon_{j}^{2}$ is the $j$-th squared error out of $n$ number of data. The parameter estimation and optimisation uses explicit Runge-Kutta algorithm (Dormand and Prince 1980) to solve the simultaneous differential equation 
numerically, then Nelder-Mead simplex algorithm optimises it (Lagarias et al. 1998). We develop the code in MATLAB as a platform for parameter estimation and optimisation.

\section{Results}

\section{Proposed models}

\section{Biosurfactant-producing bacteria growth (BBG Model)}

This research proposes similar model such as Eq. (1). We found a mismatch between Eq. (1) and the predator model; also known as Lotka-Volterra model in Eq. (5).

$\frac{\mathrm{d} x}{\mathrm{~d} t}=\alpha x-\beta x y$

$-\frac{\mathrm{d} y}{\mathrm{~d} t}=\gamma y-\delta x y$.

The biosurfactant-producing bacteria growth model uses the predator-prey model as in Eq. (6).

$\frac{\mathrm{d} P}{\mathrm{~d} t}=\mu_{1} P-\gamma P S$

$-\frac{\mathrm{d} S}{\mathrm{~d} t}=\mu_{2} S-\delta P S$

The logistic growth model transforms Eq. (6) into (7).

$\frac{\mathrm{d} P}{\mathrm{~d} t}=\mu_{1} P-\frac{\mu_{1}}{K_{0}} P^{2}-\gamma P S$

$-\frac{\mathrm{d} S}{\mathrm{~d} t}=\mu_{2} S-\delta P S$

The idea of predator-prey is that the predator and prey are interacting towards each other. This phenomenon supports the modification of Eq. (1) into (7) because $P$ and $S$ must interact. Predation and interaction factor appears as $\gamma$ and $\delta$, respectively. This research explores which model provides better approximation for the experimental data. This paper also proposes that the designation of global growth rates $\mu_{1}$ and $\mu_{2}$ should be consistent, where $\mu_{1}$ is used for $P$ and $\mu_{2}$ is used for $S$ so that the parameters' dimension is consistent. We recommend that $P$ and $S$ must be normalised by $1 \mathrm{cel} / \mathrm{mL}$ and $1 \mathrm{~g} / \mathrm{L}$, respectively, so that both variables are finally dimensionless. The term "quasi-dimension" appears to overcome this confusion.

This research proposes another model that is modified from the existing model (Eq. 1, Halim et al, 2009), the consistent model, as shown by a set formula in Eq. (8). The term "consistent" means the growth constant is $\mu_{1}$ for controlling $P$. $\frac{\mathrm{d} P}{\mathrm{~d} t}=\mu_{1} P-\frac{\mu_{1}}{K_{0}} P^{2}-\gamma P S$

$\frac{\mathrm{d} S}{\mathrm{~d} t}=\mu_{1} P-\delta P S$.

The large carrying capacity $K_{0}$ can diminish the second term in RHS of Eq. (8). It leads to another alternative model as shown by Eq. (9).

$\frac{\mathrm{d} P}{\mathrm{~d} t}=\mu_{1} P-\gamma P S$

$\frac{\mathrm{d} S}{\mathrm{~d} t}=\mu_{1} P-\delta P S$.

The last model aims to check the effect of parameter consistency towards the model. The second inconsistent model is shown as Eq. (10). "Inconsistent" term signifies the inconsistent quasi-dimension that $\mu_{1}$ for the growth of $P$ and $S$ depends on their own concentration. Variable $S$ should have its own constant, i.e. $\mu_{2}$.

$\frac{\mathrm{d} P}{\mathrm{~d} t}=\mu_{1} P-\frac{\mu_{1}}{K_{0}} P^{2}-\gamma P S$

$-\frac{\mathrm{d} S}{\mathrm{~d} t}=\mu_{1} S-\delta P S$.

In summary, the inconsistent models are Eqs. (1) and (10); and the consistent models emerge in Eqs. (7)-(9).

\section{Rate estimation model (REM)}

The rate parameters in Eq. (1): growth rate $\mu_{1}$ and biosurfactant production rate $\mu_{2}$ can be estimated with parameter estimation method such as multivariate regression or differential equation solution fitting. The rate parameters should vary through the time instead of using global growth rates. Equation (11) covers the proposed rate estimation model (REM). The estimated rate will be discrete because it follows the use of discrete experimental data point. We suggest using polynomial regression to capture the trend of the estimated rate. These results in a continuous time-dependent rate model $\mu=f(t)$.

$\mu_{M}=\frac{\ln \left(\frac{M}{M_{i}}\right)}{t-t_{i}}$

$M$ is either bacteria population $P$ or biosurfactant concentration $S, t$ is time $\mathrm{h}$, and $M_{i}$ is $M$ at initial condition $t_{i}$.

The initial condition sets the time step of the data as assumed in "Biosurfactant-producing bacteria growth model". Indeterminate form emerges at the application of 
initial condition to Eq. (11), hence, we exclude it from the rate estimation. Important to note that bacteria may grow differently as they are supplied with different nutrients. We draw this thought because different nitrogen sources can influence bacteria to degrade $n$-alkane in unique manner (Purwasena et al. 2014).

\section{Interfacial tension response (IFT model)}

The authors propose an IFT model as shown by Eq. (12). We assume a general IFT for the whole ranges of biosurfactant concentrations from $S<S_{\mathrm{CMC}}$ to $S>S_{\mathrm{CMC}}$. The IFT at near
CMC is considerably the interface of oil-water only. Otherwise, there exists microemulsion at $\sigma>\sigma_{\mathrm{CMC}}$, hence there are three interfaces being considered: oil-water, microemulsion-water, and microemulsion-oil.

$\frac{\sigma-\sigma_{\mathrm{CMC}}}{\sigma_{0}-\sigma_{\mathrm{CMC}}}=\operatorname{erfc}(K S)$.

Equation (13) results from Eq. (12) rearranged into a more convenient form.

$\sigma=\sigma_{\mathrm{CMC}}+\left(\sigma_{0}-\sigma_{\mathrm{CMC}}\right) \operatorname{erfc}(K S)$.
Fig. 1 Workflow of the integrated model

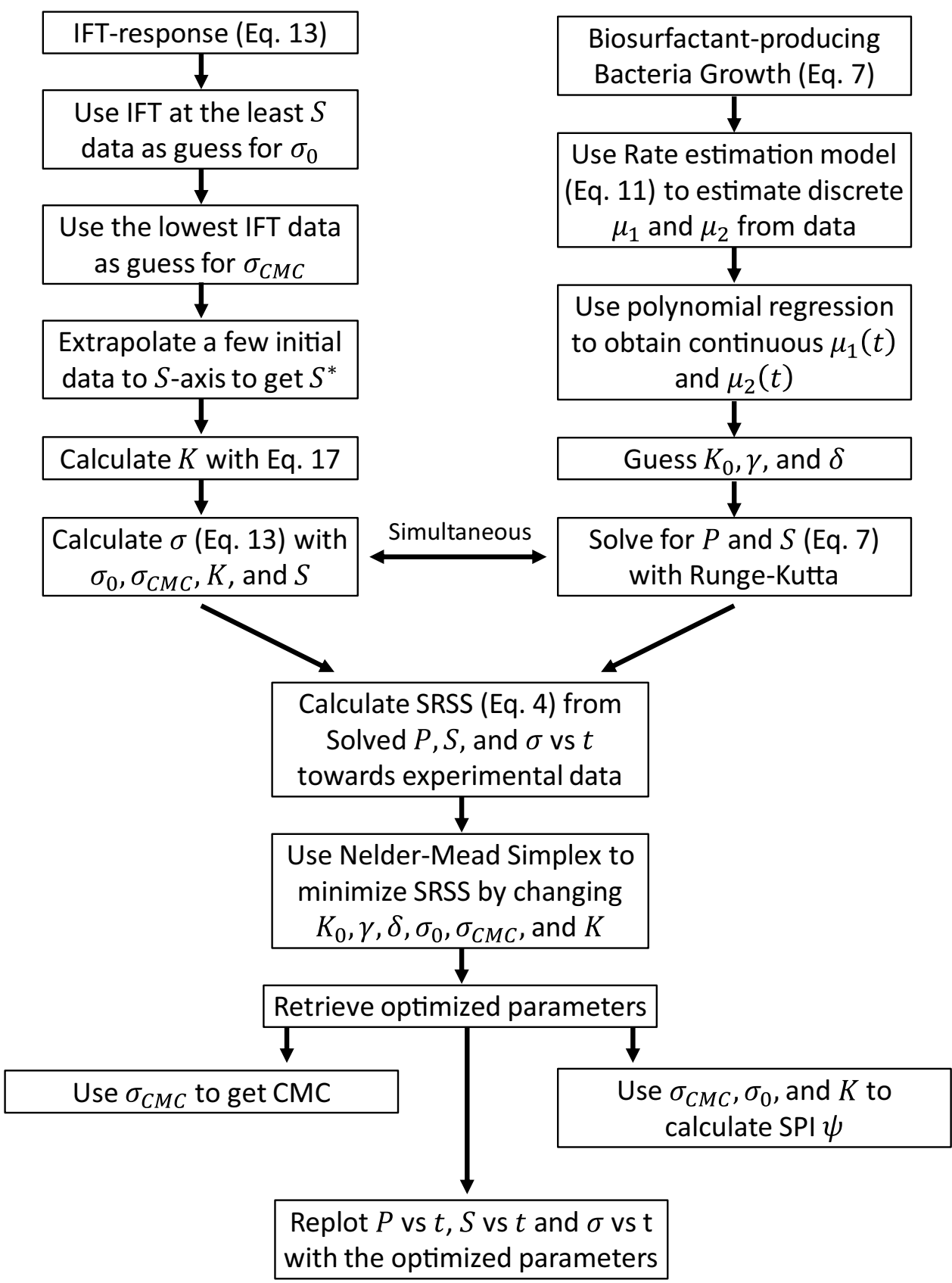


The subscripts assert the surfactant concentration. Therefore, $\sigma_{0}$ means the IFT at zero-surfactant concentration and $\sigma_{\mathrm{CMC}}$ means the IFT at CMC $(\mathrm{mN} / \mathrm{m}) . S$ is surfactant concentration $(\mathrm{g} / \mathrm{L})$ and $K$ is surfactant performance constant $(\mathrm{L} / \mathrm{g})$. However, we present the $S$ and $K$ both are dimensionless because they are normalised by $1 \mathrm{~g} / \mathrm{L}$ and $1 \mathrm{~L} / \mathrm{g}$, respectively, to avoid confusions due to the existence of growth constants. The function erfc is a complementary error function. Note that the model is applicable to either biosurfactant or surfactant. Equation (13) can estimate the parameters and the ability to compare surfactant performance quantitatively by means of surfactant performance index $\psi$.

\section{Coupled-simultaneous model (CSM)}

The coupling of proposed models (Eqs. 7 and 13) into first three simultaneous model shown as Eq. (14). This provides an integrated model of bacteria growth and IFT-response. Figure 1 displays the workflow of how to use the coupled model. The model assumes that the external varying factors such as temperature, $\mathrm{pH}$, salinity, and surfactant affinity are constant. The surfactant affinity itself depends on temperature, $\mathrm{pH}$, salinity, surfactant compositions (hydrophilic lipophilic balance HLB), and also oil composition (Salager et al. 2000). A MEOR bacteria, Pseudoxanthomonas sp. G3, for instance, can withstand with emulsion level up to $50 \%$ $(\mathrm{v} / \mathrm{v})$, wide $\mathrm{pH}$ range (2-12), and salinity up to $10 \%$ of $\mathrm{NaCl}$ (w/v) (Astuti et al. 2019). A latter comprehensive study has modelled IFT and phase behaviour relations for a wide range of surfactant affinity conditions (see Eq. 14d; Torrealba and Johns 2017). The model covers three phases due to the presence of microemulsion. We adapt it in a simplified case for the least IFT, i.e. no hydrophilic-lipophilic deviation (HLD $=0$ ). This implies that the IFT would only be at oil-water interface (Torrealba and Johns 2017). Our model focus is to link it to the bacteria-surfactant interactions.

$\frac{\mathrm{d} P}{\mathrm{~d} t}=\mu_{1} P-\frac{\mu_{1}}{K_{0}} P^{2}-\gamma P S$

$-\frac{\mathrm{d} S}{\mathrm{~d} t}=\mu_{2} S-\delta P S$

$\sigma=\sigma_{\mathrm{CMC}}+\left(\sigma_{0}-\sigma_{\mathrm{CMC}}\right) \operatorname{erfc}(K S)$

$\sigma_{\mathrm{CMC}}=c_{\gamma} H L D^{2}+\sigma_{\mathrm{ow}}^{\min }$

Parameters $\mu_{1}$ and $\mu_{2}$ are directly estimated with REM (Eq. 11). Variable $c_{\gamma}$ is a constant and derived in the literature (Torrealba and Johns 2017). The graphical method estimates the parameters $\sigma_{\mathrm{CMC}}, \sigma_{0}$ and $K$ ("Surfactant Performance Index $\psi$ "), and together with $\gamma$ and $\delta$ will be tuned to achieve minimum SRSS with Nelder-Mead simplex algorithm. The SRSS is calculated from history data (timebased only) includes the IFT model because IFT can be a function of $S$ or $t$.

\section{Surfactant performance Index $\psi$}

Nelder-Mead simplex algorithm needs an initial guess for each parameter. The graphical approach can narrow the guess ranges for the proposed IFT-response model. A consideration of how good surfactant performance is the ability to obtain IFT as low as possible with the least CMC. Thus, we define surfactant performance index $\psi(\mathrm{mN} / \mathrm{m})$ as Eq. (15). Typical surfactant by bacteria cannot reduce IFT up to smaller order like a synthetic surfactant, for example, by an anionic ethoxy carboxylate at $4 \times 10^{-4} \mathrm{mN} / \mathrm{m}$ (Hakiki et al. 2015). Hence, a synthetic surfactant with an oil-water IFT of $10^{-1} \mathrm{mN} / \mathrm{m}$ has a similar performance index $\psi$ than a surfactant with an oil-water IFT of $10^{-3} \mathrm{mN} / \mathrm{m}$, in fact, their oil-mobilisation behaviour is markedly different. Thus, surfactant performance index $\psi$ in linear fashion such as Eq. (15) is suitable for biosurfactant case. Further study for more options of synthetic surfactants should extend performance index $\psi$ in logarithm trend instead of linear.

$\psi=\left(\sigma_{0}-\sigma_{\mathrm{CMC}}\right) K$.

This index can work to compare several surfactants and estimate $K$ for an initial guess. The initial gradient of the IFT-response is calculated with the first derivative of Eq. (13) with respect to the surfactant concentration. This is $2 \psi / \sqrt{\pi}$ (see "Appendix"). The initial gradient is, thus, equal to $\sigma_{0} / S^{*}$ (Eq. 16) where $S^{*}$ is an extrapolated surfactant concentration (see Fig. 2a).

$\frac{2 \psi}{\sqrt{\pi}} \approx 1.13 \psi=\frac{\sigma_{0}}{S^{*}}$

$S^{*}$ is an extrapolated surfactant concentration. Equation (17) appears to compute surfactant performance constant $K$.

$K=\frac{\sqrt{\pi}}{2 S^{*}} \frac{\sigma_{0}}{\left(\sigma_{0}-\sigma_{\mathrm{CMC}}\right)}$

Figure $2 \mathrm{~b}, \mathrm{c}$ depicts the procedure to determine initial guesses for IFT-response model parameters $K, \sigma_{0}$, and $\sigma_{\mathrm{CMC}}$. Figure $2 \mathrm{~d}$ provides exemplary data from perturbed Eq. (13) to withdraw the value of the parameters. Figure $2 d$ illustrates the sensitivity of surfactant performance constant $K$. 
Fig. 2 Surfactant performance constants. a The initial gradient is $2 \psi / \sqrt{\pi}$. The gradient can also be calculated by dividing the opposite and adjacent side, which is $\sigma_{0} / S^{*}$. Equating both gradient results in Eq. (16). b $\sigma_{0}$ is estimated with the initial IFT, $\sigma_{\mathrm{CMC}}$ is estimated by horizontal line of the lower boundary of the trend, and $K$ is estimated by with Eq. (17). c Example on using graphical method to obtain approximate value of parameters in Eq. (13). Calculate $K$ with Eq. (17) results in $K=0.56$. Hence, plotting Eq. (13) with $\sigma_{0}=15 \mathrm{mN} / \mathrm{m}$, $\sigma_{\mathrm{CMC}}=6.2 \mathrm{mN} / \mathrm{m}$ and $K=0.56$ results in frame d. d Sensitivity of $K$ to IFT with a dummy data (a)

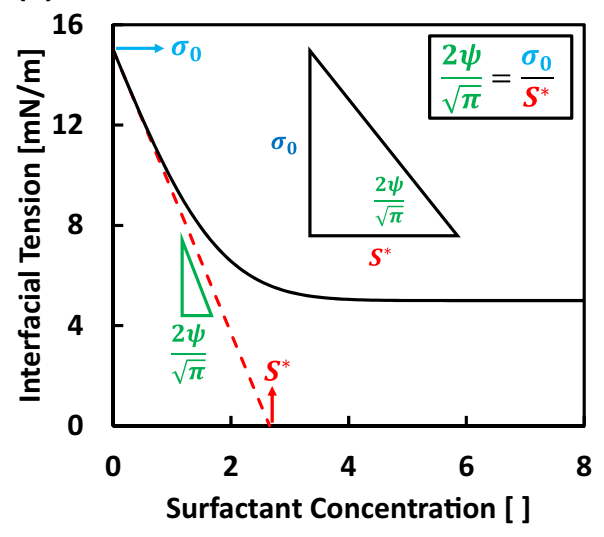

(c)

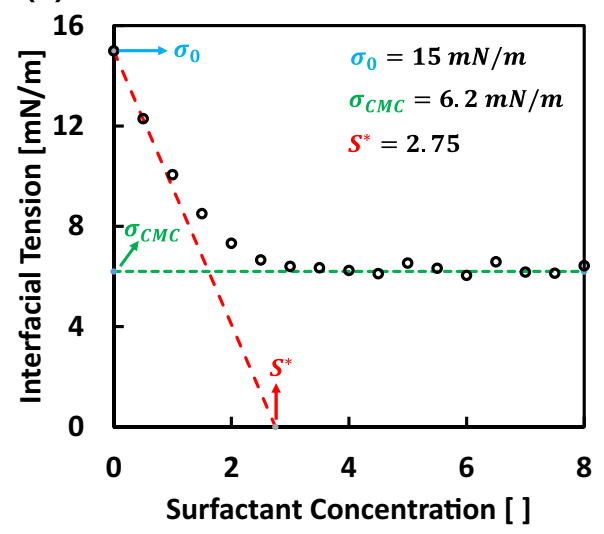

(b)

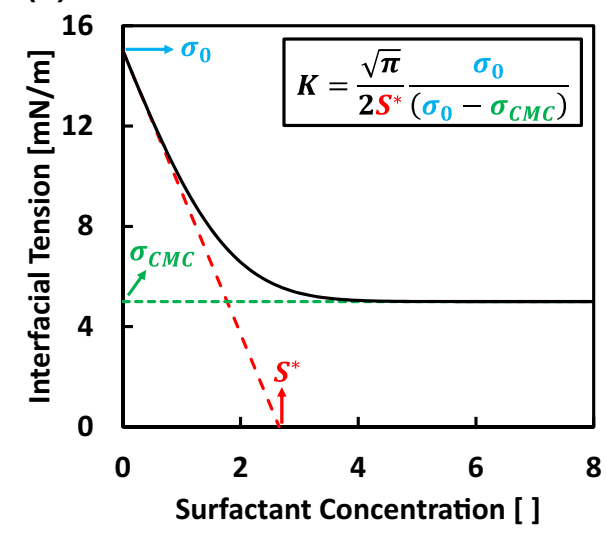

(d)

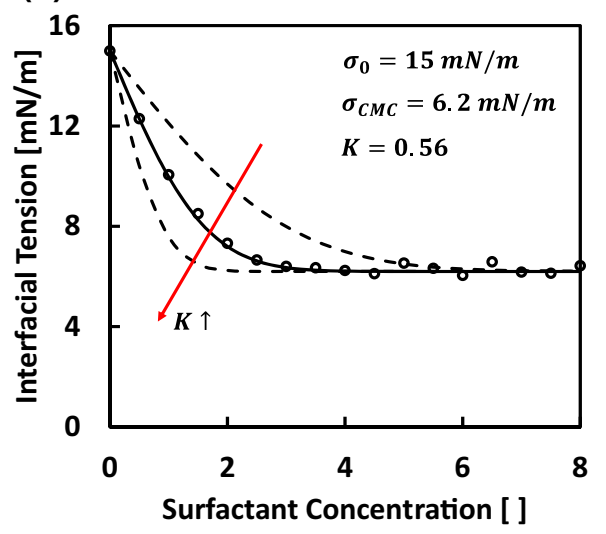

\section{Discussion}

This research delivers an exploration on the suitability of dynamic models. These include bacteria and the selected metabolite, i.e. biosurfactant. The paper addresses to question whether the global growth rates $\mu_{1}$ and $\mu_{2}$ should exist to multiply for each $P$ and $S$, respectively; or there should only be $\mu_{1}$. Once we select $\mu_{1}$ only, there will be next questions whether that the biosurfactant production depends on the population $\mathrm{d} S / \mathrm{d} t \propto \mu_{1} P$ (see Eq. 9); or depends on the surfactant concentration $\mathrm{d} S / \mathrm{d} t \propto \mu_{1} S$ (see Eq. 10).

Equations (1), (8), and (9) emphasise that the growth of population and biosurfactant relies only on population regardless of the growth constant either $\mu_{1}$ or $\mu_{2}$. Reverse case applies for Eqs. (7) and (10) to describe that growth of population and biosurfactant depends on their own.

This paper introduces terms "inconsistent" and "consistent" to differentiate the quasi-dimension consistency. The term "inconsistent" is applicable for Eqs. (1) and (10); and the "consistent" is for in Eqs. (7)-(9). "Consistent" signifies that $\mu_{1}$ multiplies $P$ and $\mu_{2}$ works for $S$. The ultimate model is the Eq. (14). This equation set designates coupled-simultaneous computation and results from Eqs. (7) and (13) and a multiphase IFT model (Torrealba and Johns 2017).

\section{BBG model}

Without REM: Table 4 presents the parameter estimation results and SRSS. The proposed "consistent" models (Eqs. 7-9) have relatively similar SRSS with "inconsistent" model (Eq. 1), except for Eq. (7) with DATA 1C. Figure 3 describes the modelling results in detail.

The parameter values of Eqs. (1) and (7) are insignificantly different except $\mu_{2}$. The values of $\mu_{2}$ in Eq. (7) are higher than in Eq. (1) up to two orders of magnitude. This informs that $\mu_{2}$ salient controls $S$ than $P$.

Figure 3 illustrates that the results from Eqs. (8) and (9) are indistinguishable. The errors in Table 4 also claim that they are almost exact because the value of carrying capacity in Eq. (8) is huge. If $K_{0} \rightarrow \infty$, there is no interaction between bacteria $\mu_{1} / K_{0} \rightarrow 0$. The factor $\mu_{1} / K_{0}$ actually points the inter-bacteria interactions, e.g. competition in nutrient consumption. In mammalian creatures, the $\mu_{1} / K_{0}$ may mean an intercourse factor to promote the growth and a competition factor in case of demoting the growth. 
Table 4 Parameter estimation and optimisation of BBG and IFT model

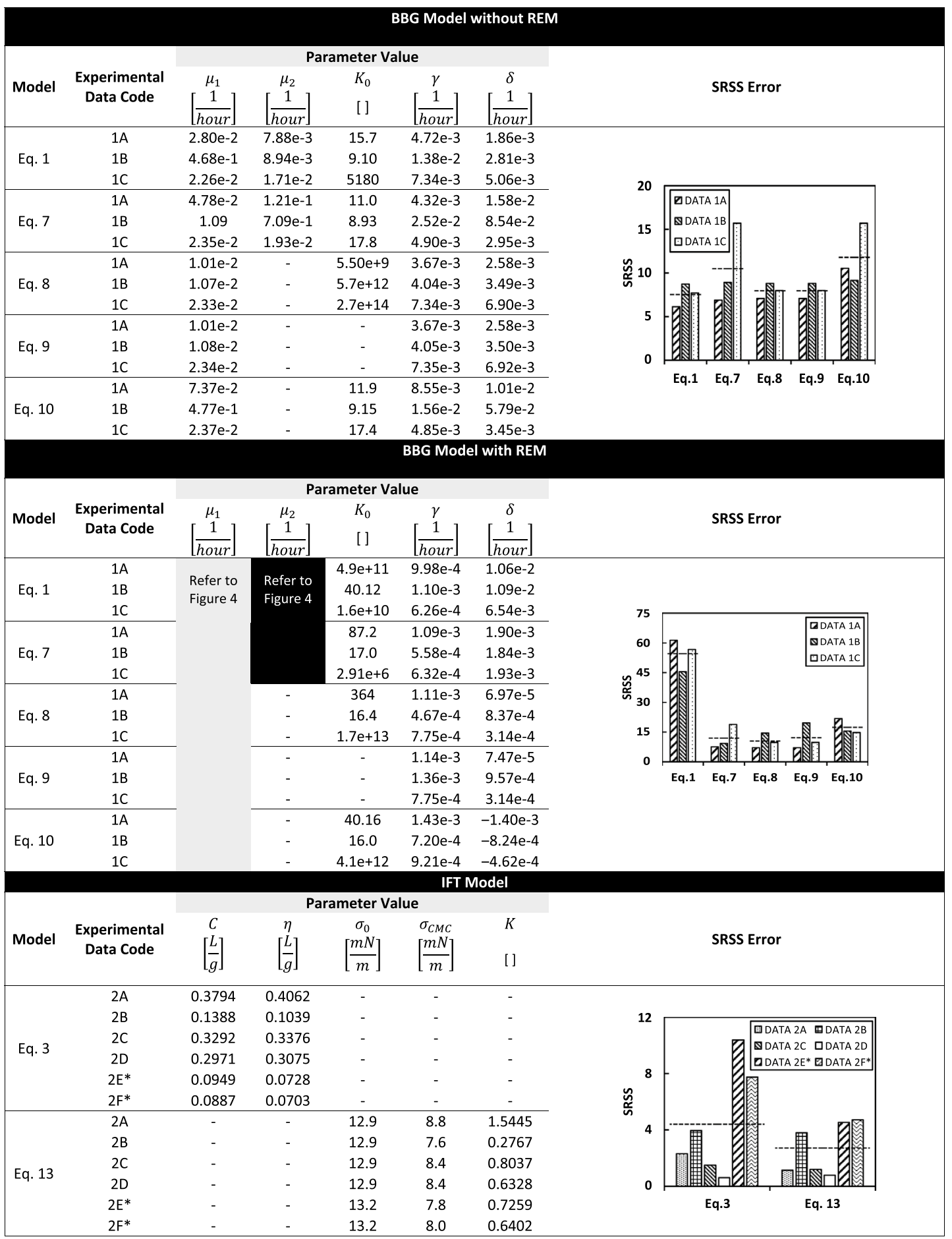

Horizontal dashed lines in SRSS plots represent the SRSS average for each equation

$B B G$ biosurfactant-producing bacteria growth, SRSS sum of residual sum of squares (see Eq. 4)

The parameter values except $\mu_{2}$, SRSS and the numerical results from Eq. (10) are similar to Eq. (7). DATA 1A and 1B have a concentration "peak" around $120 \mathrm{~h}$ and Eq. (1) cannot capture this peak even it has the least error. Equations (7) 
and (10) capture the peaks with DATA 1A. Comparison of parameter values in Eqs. (7) and (10) concludes that the term $\mu_{2} P$ in Eq. (1) is negligible. Obvious control in the surfactant growth $\mathrm{d} S / \mathrm{d} t$ is the predation or interaction activity between $P$ and $S$.

With REM: This paper develops REM to span growth duration from initial time to maximum simulated time, $170 \mathrm{~h}$. A growth model may make a dichotomy of "growth" and "death" to address the cultivating and declining population (Jones and Walker 1993). This REM works for a general change in the number of population includes the declining population. We do not segregate the growth and death REM like an earlier study on Petrotoga sp. (Daryasafar et al. 2014). That study limits the dynamics of populations because it is possible to have a second growth due to nutrient injection in the middle of decaying process. It means the growth constant developed by that literature needs the latest data to update the model.

The study uses Eq. (11) to establish the rate, named REM. Figure 4 represents the computed REM. Those REMs account the nature of time-dependent growth rate and biosurfactant production rate. REMs have a significant decrease in early $50 \mathrm{~h}$. It suggests supplying more nutrient in necessity of boosting the bacteria population and the consequent biosurfactant production. The parameters and SRSS for BBG model with REM may refer to Table 4. It shows that Eq. (10) is not compatible with the REM because it provides negative predation factor $\delta$ in all DATA 1 .

Figure 5 portrays the numerical results of BBG modelling with REM. Equation (1) does not show an agreement with all data because the model reaches the concentration peak at earlier time, i.e. 30 h. Equation (10) does not either confirm a trend because it exhibits a linear to exponential alike for surfactant concentration. Figure 5 confirms that BBG model with REM is in a good agreement with Eqs. (7)-(9). The SRSS error supports this statement as depicted in Table 4.

All numerical simulations using DATA $1 \mathrm{C}$ provide very high carrying capacity $K_{0}$. Only results from Eqs. (8) and (9) are similar for all data. This proves that no inter-bacteria relation $\mu_{1} / K_{0}$ should appeal even though the $K_{0}$ spans 13 orders of magnitude different. The least errors and the best curvature following the experimental data withdraws Eq. (7) as the best.

\section{IFT model}

Table 4 also specifies the parameters of IFT model. Figure 6 emerges the detailed results and compares between Eq. (3) and the proposed model, Eq. (13). Both models agree with the experimental data but Eq. (3) is limited to small concentration. Term $[1-C S \exp (-\eta S)] \rightarrow 1$ as $S \rightarrow \infty$, hence Eq. (3) will reach back initial IFT $\sigma_{0}$. Equation (13) derives more physical-sense because IFT will be at stationary for a high concentration. The erfc function gives a minute error of $\sigma\left(S_{\mathrm{CMC}}\right)$ with respect to $\sigma_{\mathrm{CMC}}$ and cannot hit an exact equality. The magnitude of $\sigma_{0}$ is in the order of $10-100 \mathrm{mN} / \mathrm{m}$, $\sigma_{\mathrm{CMC}}$ is in the order of $1-10 \mathrm{mN} / \mathrm{m}$, and $K$ is in the order of $0.1-10 \mathrm{~L} / \mathrm{g}$. The deviations of IFT at around of CMC are not observable (Fig. 6). Thus, the use of erfc is still reasonable in this range.

All data of the least IFT and the CMC are more or less same for all surfactants. Figure 7 summarises the surfactants in the sense of surfactant performance index $\psi$. The surfactant performance index (SPI) recommends the scheme applied in DATA 2A because it displays the highest $\psi$. The scheme is the 1:1 consortium of Bacillus sp. and Bacillus polymyxa with $0.01 \%(\mathrm{~m} / \mathrm{v}) \mathrm{NPK}$ and $20 \%$ (v/v) crude oil. This recommendation concurs with the conclusion in the literature (Bitticaca 2009).

The graphical method of $\psi$ determination is influenced by $S^{*}$ because all cases work on the same oil sample (same $\sigma_{0}$; see Eq. 16). This extrapolated surfactant concentration $S^{*}$ is an indirect indication of CMC. The least CMC must have a smaller $S^{*}$. The advantage of $\psi$ is that it does cover how much the reduction of IFT $\left(\sigma_{0}-\sigma_{\mathrm{CMC}}\right)$ and how fast $\sigma$ to decay and reach CMC. The aim of surfactant selection is to obtain the least CMC and the lowest IFT. However, some surfactants may experience an IFT rise as the concentration greater than CMC (Hakiki et al. 2015).

\section{Coupled-simultaneous model (CSM)}

Coupled-simultaneous model (CSM) use Eq. (14) and REM model, Eq. (11) because we want to capture the nature of time-dependent rate. Figure 8 depicts the CSM results and all parameters: $K_{0}, \gamma, \delta, \sigma_{0}, \sigma_{\mathrm{CMC}}$, and $K$. Figure $8 \mathrm{a}-\mathrm{e}$ is in time domain. All model extends the computation up to $\sim 200 \mathrm{~h}$. Figure $8 \mathrm{~b}$ shows that the highest concentration is at normalised $2 \mathrm{~g} / \mathrm{L}$, hence Fig. $8 \mathrm{f}$ follows this maximum value. The growth rate also notifies negative values, which means a reduction (see Fig. 8d, e).

The concern addresses the extended time, $t \geq 150 \mathrm{~h}$ because there is a possibility that biosurfactant concentration may not decrease but remains constant. The decrease of surfactant is because the computation of population undergoes a decrement. The bacteria may vanish because of nutrition deprivation and live in a dormancy stage. There is no good physical justification of why biosurfactant decrease. It is a mathematical artefact. The proper condition is that the IFT is more or less stagnant $\sim 9.7 \mathrm{mN} / \mathrm{m}$ because the biosurfactant concentration is constant. The mathematical artefact is due to the way to select growth rate, i.e. Figure 8d, e. The construction of bacteria and biosurfactant rate deploys a polynomial fitting and results in negative value.

Assumptions to elaborate the decrement of surfactant is that the bacteria "consumes" the surfactant and it is toxic

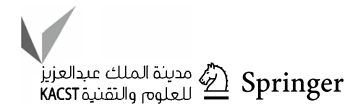



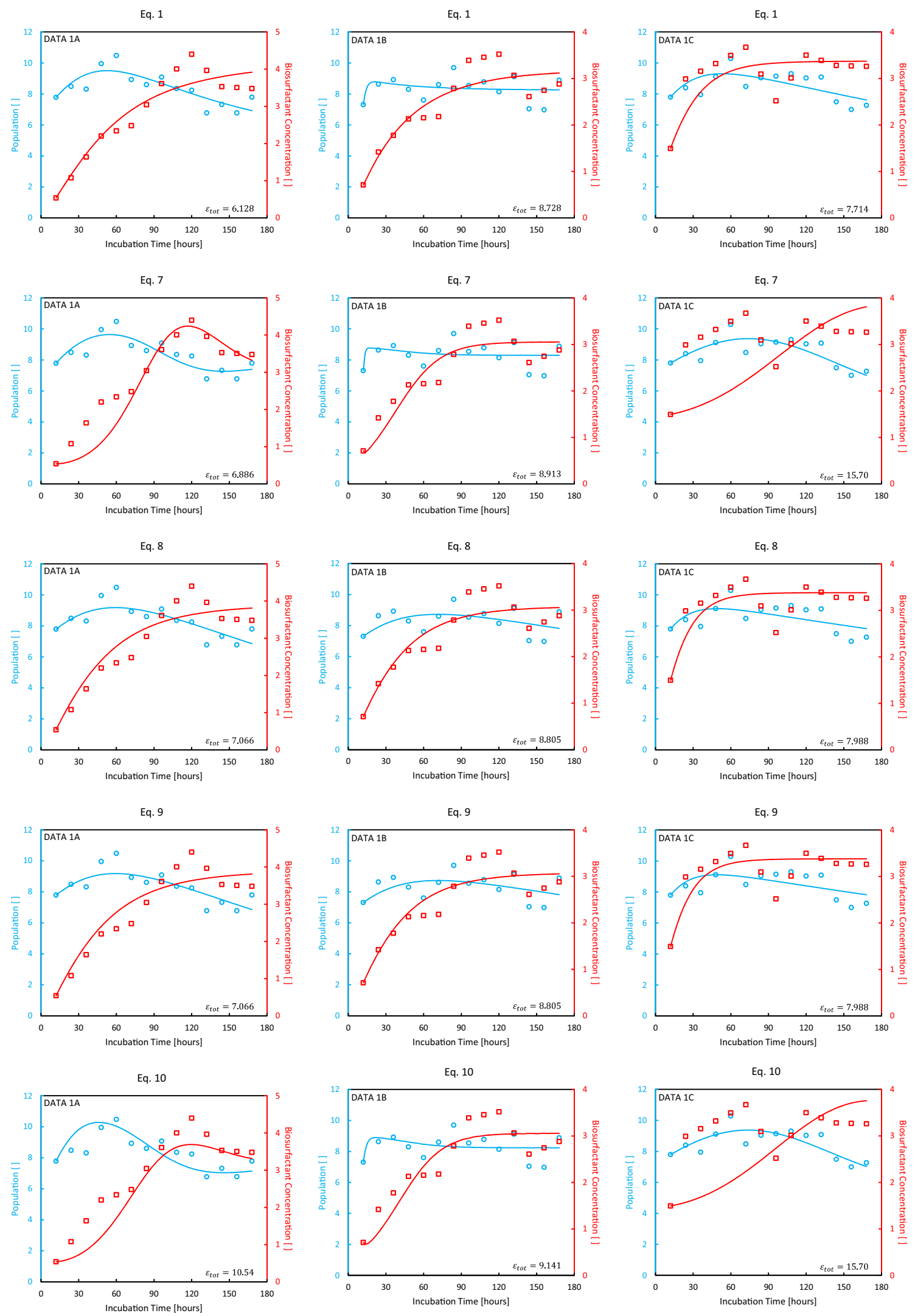
4Fig. 3 BBG modelling without REM. $B B G$ biosurfactant-producing bacteria growth, $R E M$ rate estimation model. The bacteria growth model (blue line) is overlayed with the experimental data (blue circle) and the biosurfactant concentration (red line) is overlayed with the experimental data (red square). Note that the bacteria population is in base-10 logarithmic value. The five rows represent different equations of each: 1, 7, 8, 9 and 10. The three columns use the DATA 1A, 1B, and $1 \mathrm{C}$, respectively

for them. The term of $P$ and $S$ interactions have, thus, suitable name, i.e. "toxicity constant" $\gamma$ and "predation factor" $\delta$. Some studies prove that bacteria can degrade surfactants and polymers (Scott and Jones 2000; Lucas et al. 2008). Some bacteria can use their own metabolites. These includes oxygen (Ettwig et al. 2010), methanol and acetate (Raghoebarsing et al. 2006). It requires further study whether or not bacteria consume their own metabolites, e.g. biosurfactant and understand the toxicity level to the bacteria colony or consortium. A knowledge on how the particular nutrient supply also takes a critical role in the bacteria growth (Heryani and Putra 2017). Recent study reveals that denitrification is a multistage reduction process (Song and Liu 2015). The interaction of bacteria-to-bacteria in consortium contributes an important role as well (Zheng and Li 2016; Al-Bahry et al. 2016). A further study of nutrients and metabolites consumption should be assessed together to see each contribution. An earlier study shows that organic matter follows an exponential decay degradation due to soil bacteria consumptions (Manzoni et al. 2012). An evolution in the bacteria itself is not observable in our data. A study to consider a mutation, natural assortment, or adaptive evolution may consider fractional differential equation (Ibrahim et al. 2016). However, it is unlikely to happen for MEOR bacteria.
Fig. 4 Rate estimation model (REM). The first and second columns are for bacteria and biosurfactant, consecutively. The dotted data are calculated with the proposed REM (Eq. 11) from DATA 1, which are then captured by polynomial regression (third degree) to provide continuous time-dependent growth rate and biosurfactant production rate
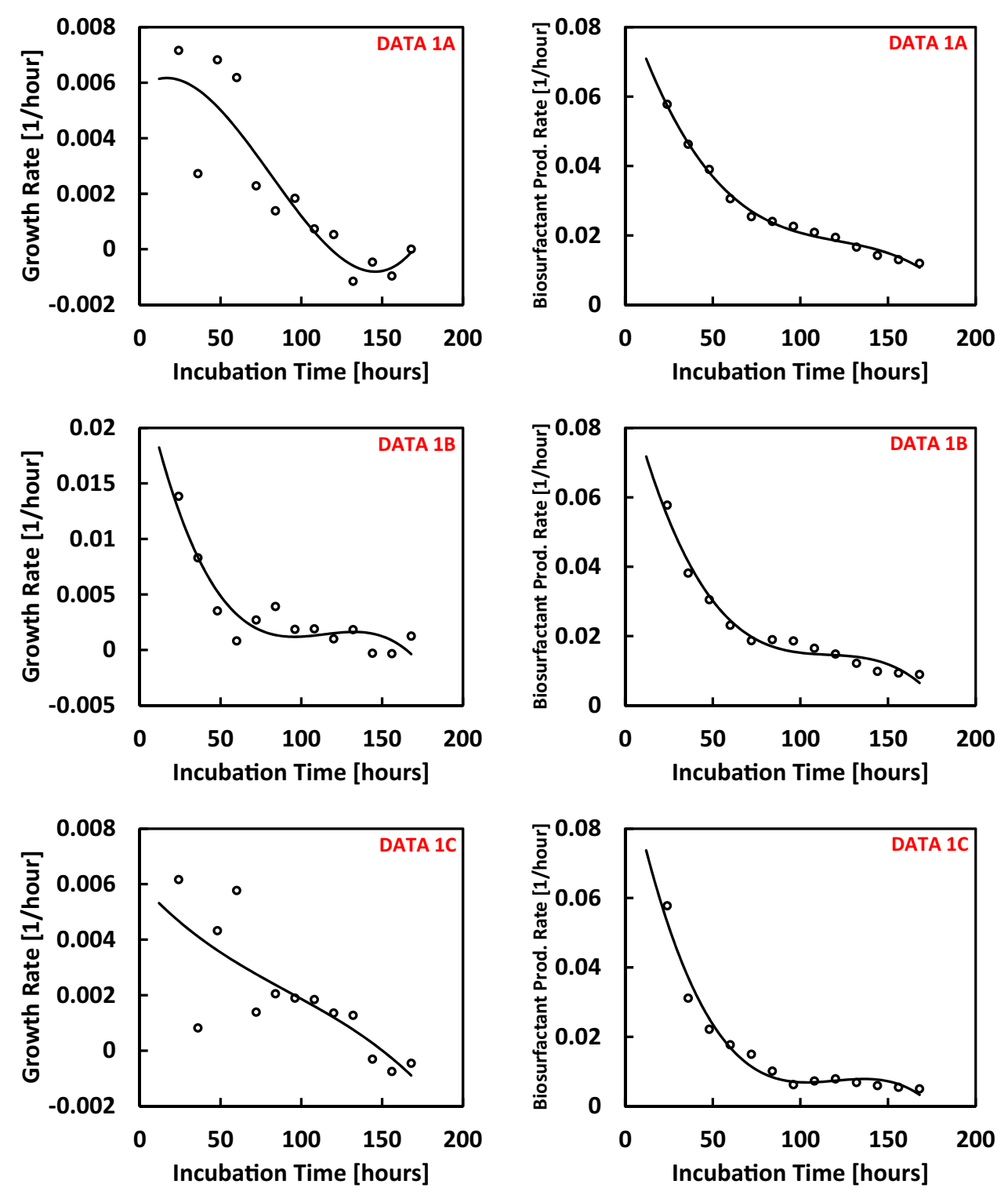
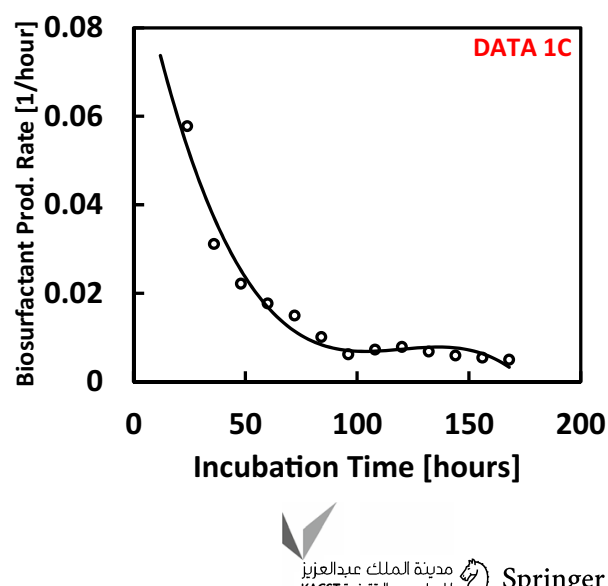

مدينة الملك عبدالعزيز KACST اللعلوم والنقنية 

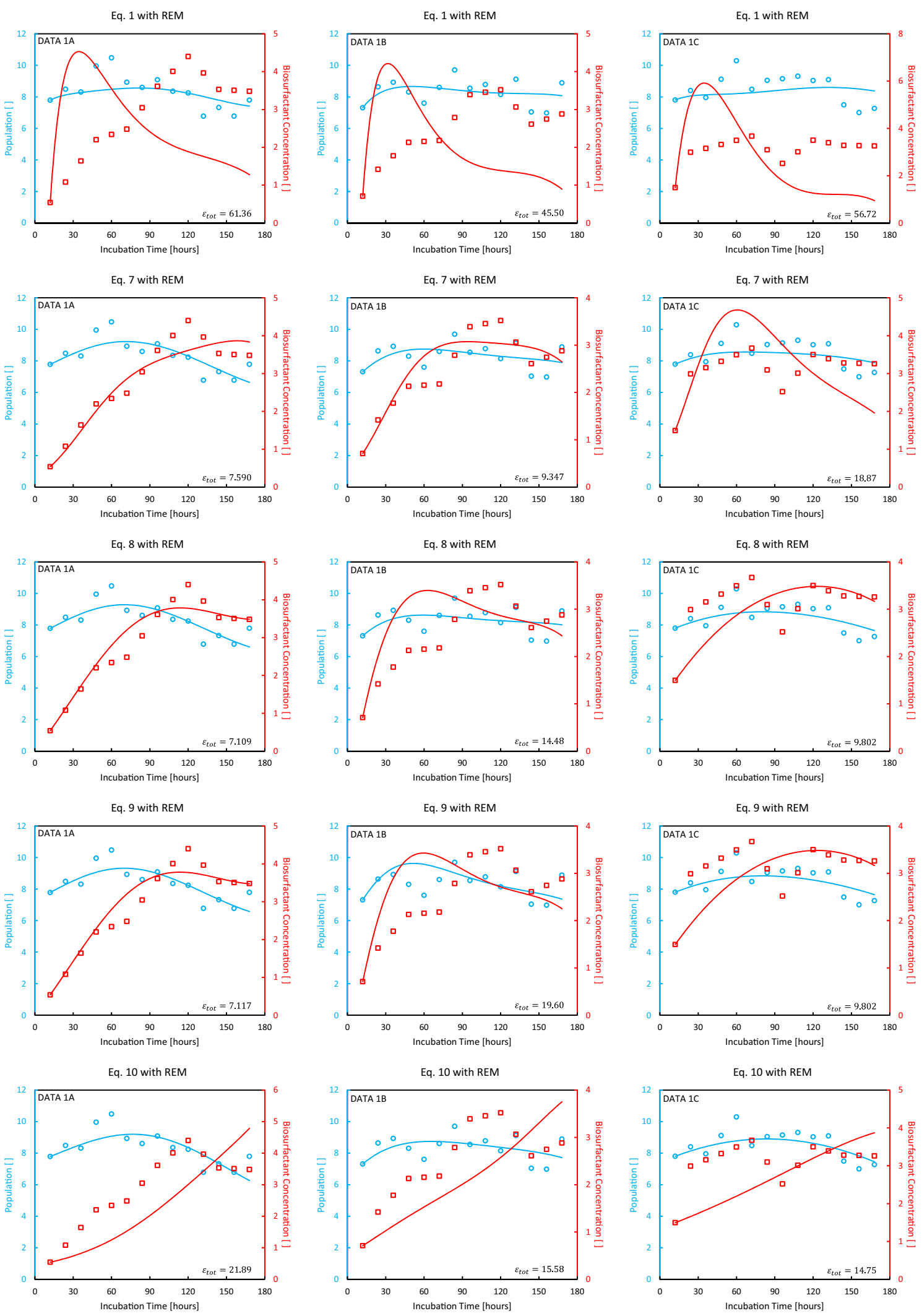

Fig. 5 BBG modelling with REM. The REM refers to Fig. 4. The bacteria growth model (blue line) is overlayed with the experimental data (blue circle) and the biosurfactant concentration (red line) is overlayed with the experimental data (red square). Note that the bac- teria population is in base-10 logarithmic value and the rate is now time-dependent following the estimated rate in Fig. 4. The five rows represent different equations of each: 1, 7, 8, 9 and 10. The three columns use the DATA $1 \mathrm{~A}, 1 \mathrm{~B}$, and $1 \mathrm{C}$, respectively 
Hakiki (2014) Model, Eq. 3
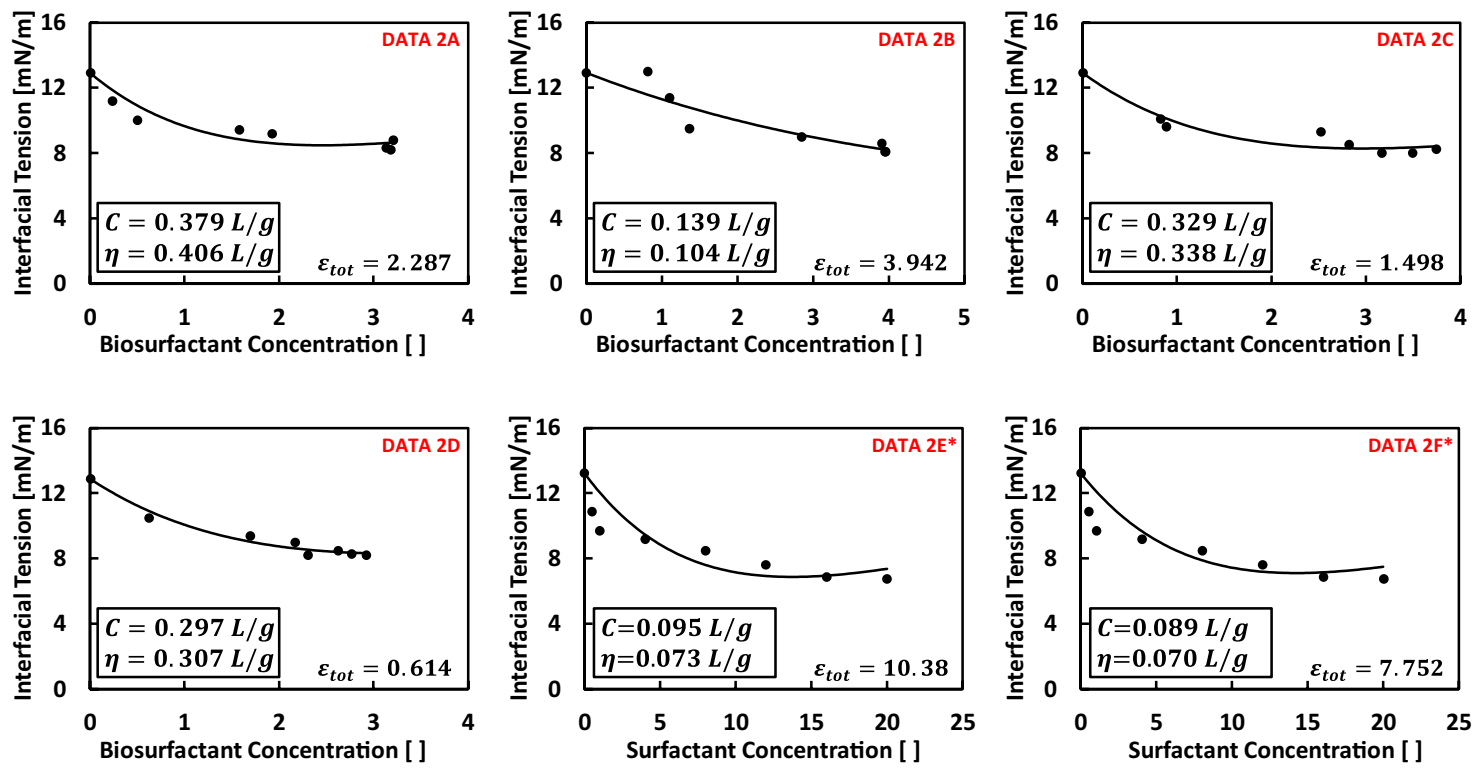

Proposed Model, Eq. 13
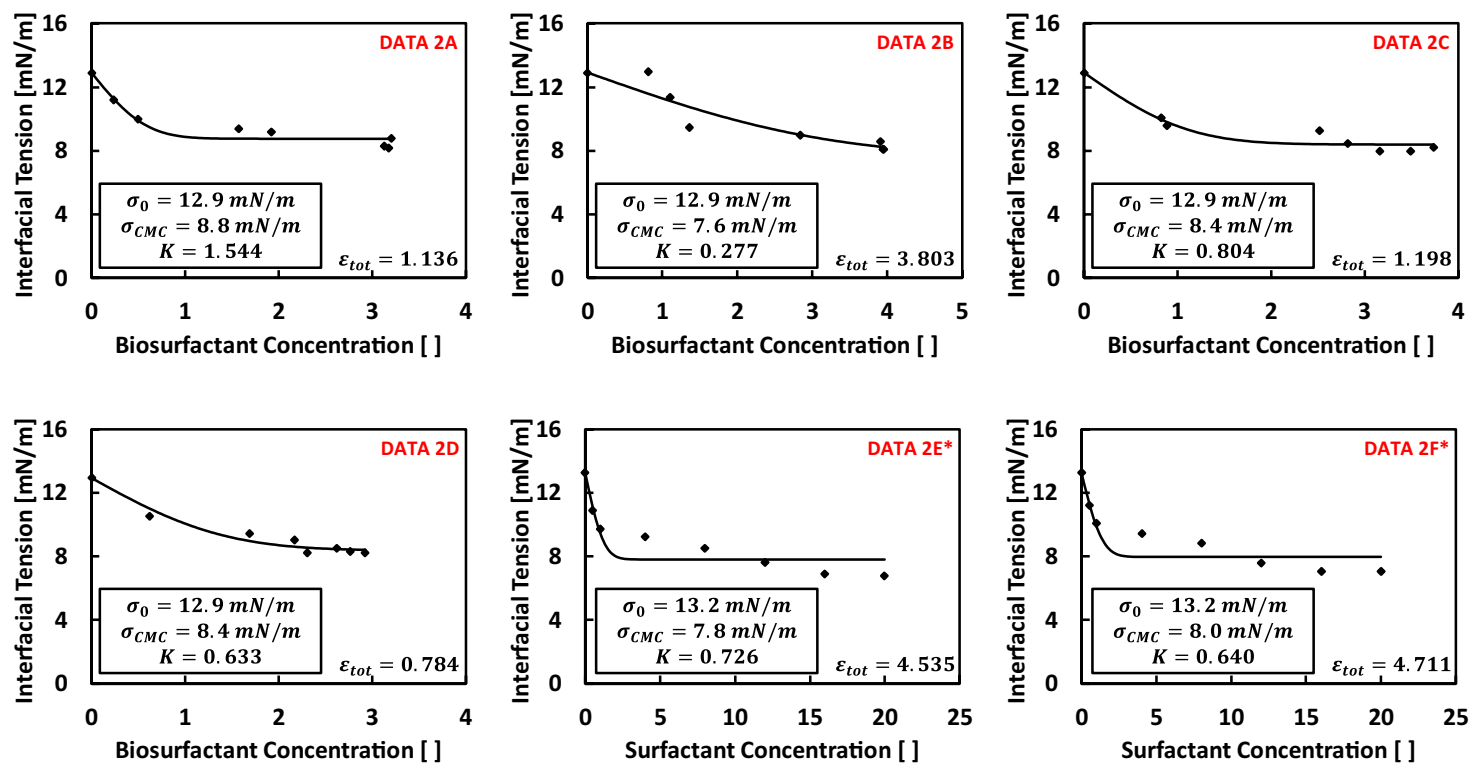

Fig. 6 IFT model. Both Eqs. (3) and (13) show good agreement towards DATA 2 even though Eq. (3) results in higher SRSS in most cases (see Table 4)

The more possible to exist is the periodicity if the nutrient and/or bacteria is reinjected. This yields a periodic pattern of solutions that may adapt an earlier study (Mohammed et al. 2017).

Figure 9 elaborates the parameter sensitivity from the fitting values to be halved and doubled. The fitting values follow the results exactly in Fig. 8. The logic in understanding the Fig. 9 results are as follow:
- Higher carrying capacity $K_{0}$ indicates a greater ability to carry more population. High population leads to more competition to consume nutrition. Hence, with the current amount of nutrition, it is not sufficient to induce more biosurfactant production. Another assumptions may interpret more bacteria bring more species to consume 


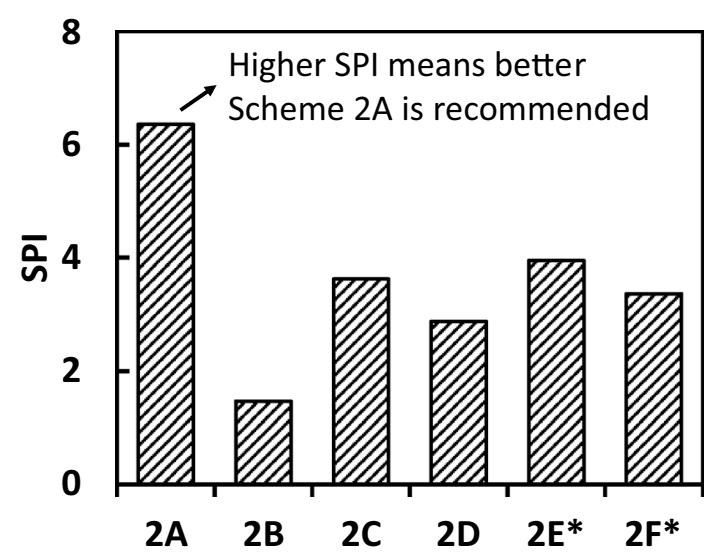

Fig. 7 Comparison of surfactant performance index $\psi$. The definition of better is the higher SPI. Higher SPI contributes to obtain the greatest IFT reduction

their biosurfactant. This eventually results in less biosurfactant concentration and higher IFT.

- Greater toxicity constant $\gamma$ guides more population reduction because it amplifies poisonous effects of biosurfactant. There is no need for in-depth physical discussion of why it causes higher biosurfactant concentration. It is because $\gamma$ belongs to population growth model $\mathrm{d} P / \mathrm{d} t$. The increased concentration is numerical artefact.

- Stronger predation factor $\delta$ reduces biosurfactant concentration due to notable effects of biosurfactant consumption by bacteria. The $\delta$ engages surfactant growth model $\mathrm{d} S / \mathrm{d} t$.

\section{Concluding remarks}

This paper has modelled the biosurfactant-producing bacteria growth and the interfacial tension-response for ex-situ microbial enhanced oil recovery study. The model has been tested to indigenous Clostridium sp. from Handil Field, East Kalimantan, Indonesia. The significant observations from the modelling and implications follow:

- There are five models to elucidate the bacteria population $P$ and biosurfactant concentration $S$ dynamics. The models include variation in the growth constants $\mu_{1}, \mu_{2}$, $\mu(t)$, inter-bacteria relation $\mu_{1} / K_{0}$, and the interaction of bacteria-biosurfactant $\gamma, \delta$.

- There are two knowledges of growth to appeal: global growth constants $\mu_{1}, \mu_{2}$ and time-dependent constants $\mu=f(t)$. The global growth constants derive a consid- (a)

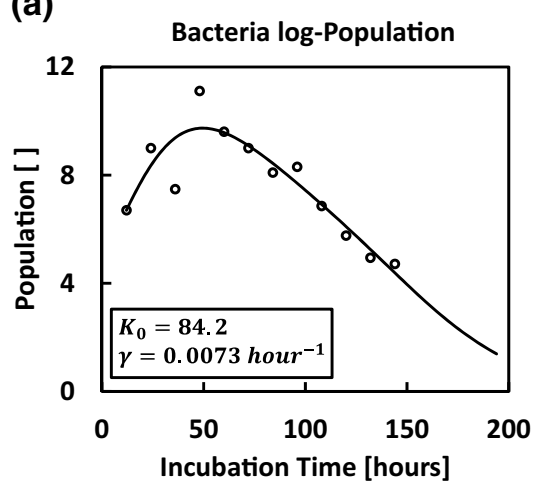

(d)

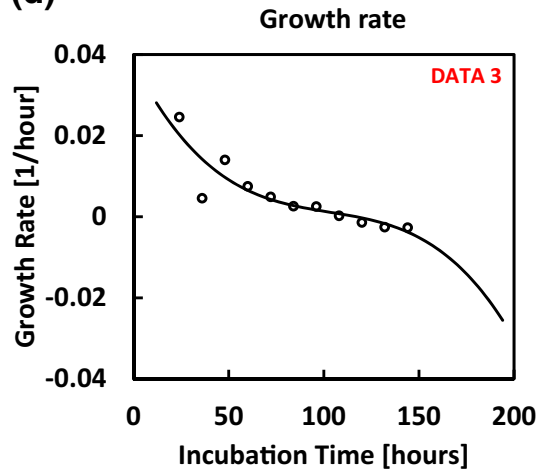

(b)

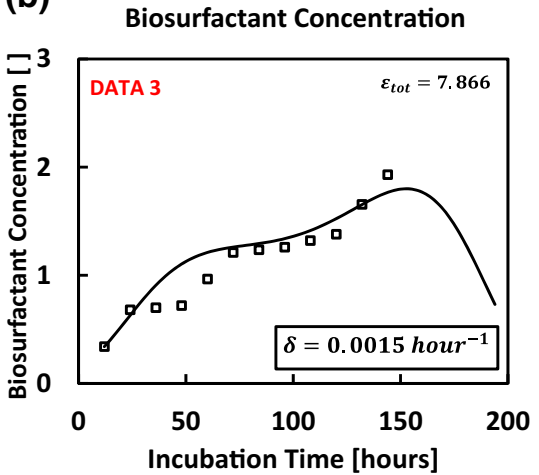

(e)

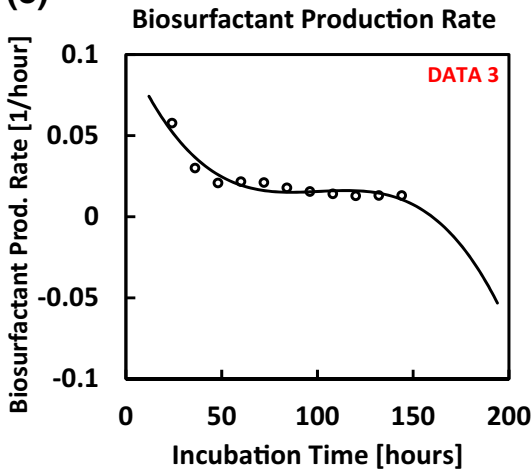

(c)

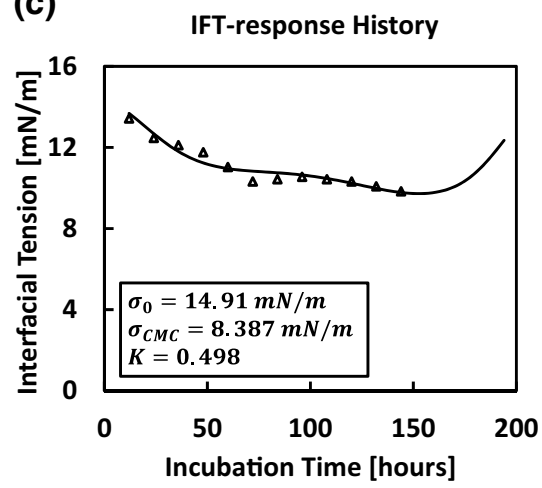

(f)

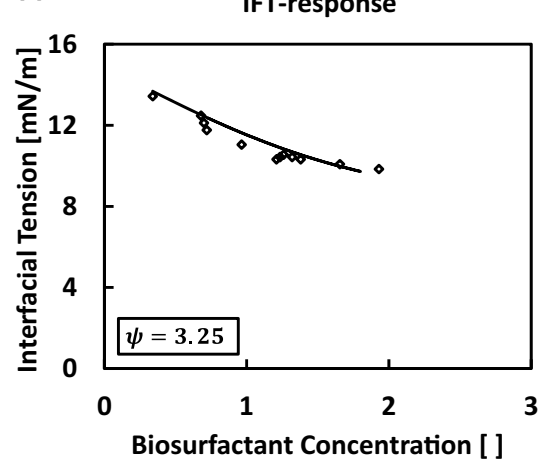

Fig. 8 Coupled-simultaneous model (CSM). The computation uses Eq. (14) and DATA 3 


\section{Population}

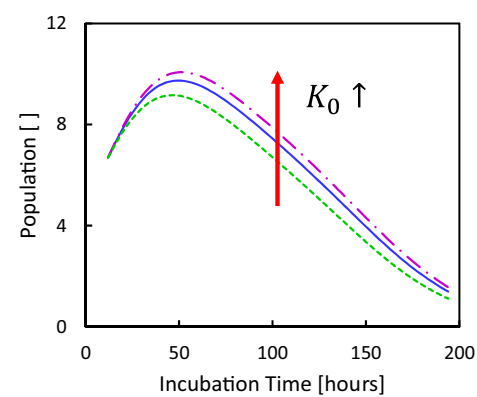

Biosurfactant Concentration

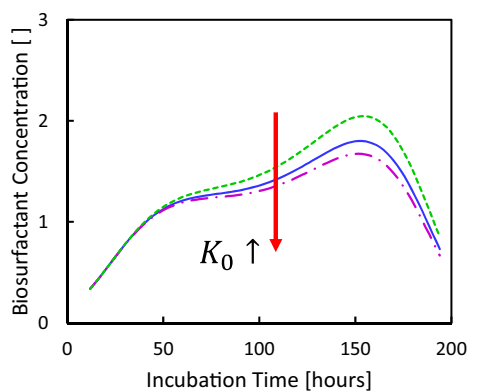

IFT

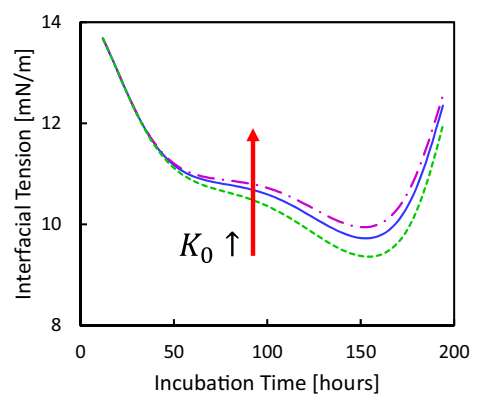

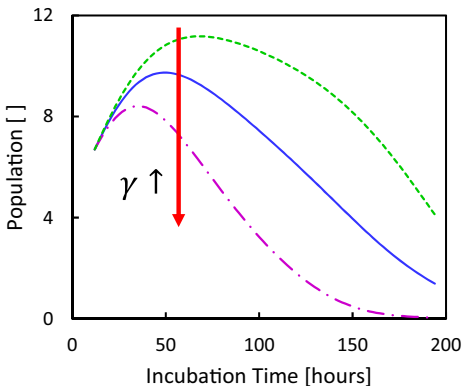
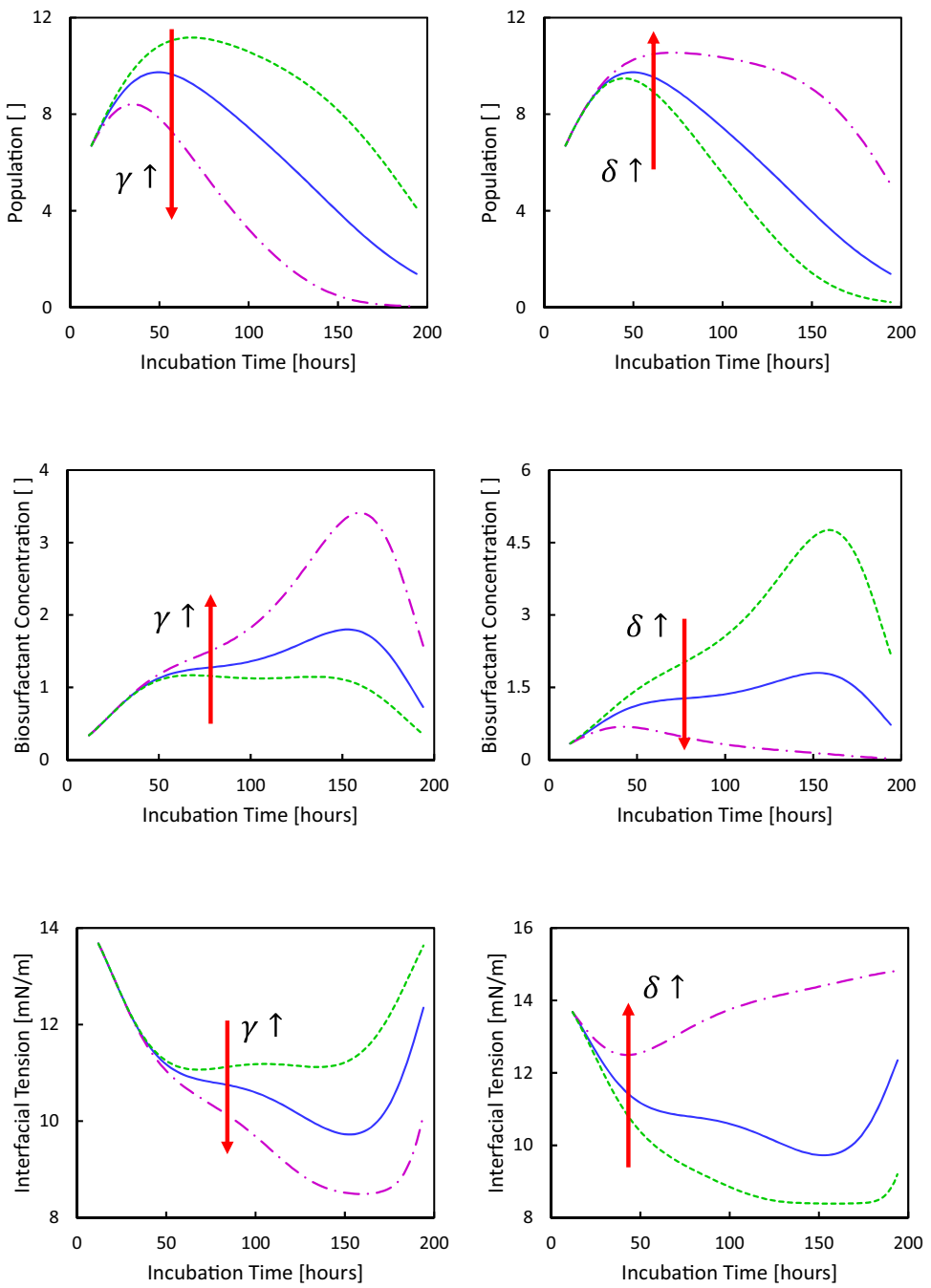

Fig. 9 Parameter sensitivity in coupled-simultaneous model. The sensitivity study uses Eq. (14) and the parameters include: carrying capacity $K_{0}$, toxicity constant $\gamma(1 / \mathrm{h})$, and predation factor $\delta(1 / \mathrm{h})$. The continuous-blue line deploys the value in Fig. 8, the halved value in dashed-green line, and the doubled value appears as dot-dashedmagenta line. There are three effects under observations: population, biosurfactant concentration, and IFT

- An integrated model couples models simultaneously: consistent bacteria-biosurfactant model and interfacial tension-response. The models account the nature of time dependent with the use of rate estimation model.

- The choice to develop rate estimation model is critical because it can contribute to numerical artefacts at the extrapolated time, $t \geq 150 \mathrm{~h}$. However, the data emerge a biosurfactant concentration peak at $\sim 120 \mathrm{~h}$ hence, there is no necessity to extent the experimental to more than $150 \mathrm{~h}$. An engineering aspect suggests soaking time is around the peak production.

- The proposed interfacial tension model and the graphical method provide a surfactant performance index $\psi$ determination which benefits to compare the perfor- 
mance of either biosurfactant or synthetic surfactant, quantitatively. Surfactant performance index $\psi$ assists to a surfactant selection in conjunction with the least amount of critical-micellar-concentration and the lowest interfacial tension attainment.

- The composition of bacteria consortium, medium, and nutrient influences the bacteria growth, surfactant production, surfactant performance index, and the critical-micellar-concentration. These data are important to decide soaking-time or well shut-off period.

An advance experimental and simulation study can engage the proposed models to see some suggested studies:

- A study whether or not to include the bacteria and/or the surfactant transport.

- Fluid transport, porosity, and permeability distribution involvement will influence the bacteria distribution.

- The distribution takes account of the initial population and the growth.

- Porosity and permeability reduction due to bacteria entrapments.

- Study on the supplied nutrition. How it would affects the equations and the significances.

- Bacteria-to-bacteria interactions.

Acknowledgements We appreciate Dr. Dea Indriani Astuti and Dr. Isty Adhitya Purwasena for providing the experimental data and $\mathrm{Mr}$. Johannes Angkawijaya for the references. An initial help by Ms. Karunia Hesti to gather literature study is acknowledged.

\section{Compliance with ethical standards}

Conflict of interest Authors confirm no conflict of interests and no financial issues.

Open Access This article is distributed under the terms of the Creative Commons Attribution 4.0 International License (http://creativeco mmons.org/licenses/by/4.0/), which permits unrestricted use, distribution, and reproduction in any medium, provided you give appropriate credit to the original author(s) and the source, provide a link to the Creative Commons license, and indicate if changes were made.

\section{Appendix}

The first derivative of Eq. (13) towards biosurfactant concentration is shown as follows:

$\frac{\mathrm{d} \sigma}{\mathrm{d} S}=\left(\sigma_{0}-\sigma_{\mathrm{CMC}}\right) \frac{\mathrm{d}}{\mathrm{d} S}[\operatorname{erfc}(K S)]$.

The derivative of the error function comes up as follows:

$\frac{\mathrm{d}}{\mathrm{d} x} \operatorname{erfc}(x)=-\frac{2}{\sqrt{\pi}} \exp \left(-x^{2}\right)$
We can obtain Eq. (20) by means of chain rule.

$\frac{\mathrm{d} \sigma}{\mathrm{d} S}=-\left(\sigma_{0}-\sigma_{\mathrm{CMC}}\right) K\left\{\frac{2}{\sqrt{\pi}} \exp \left[-(K S)^{2}\right]\right\}$

The first derivative evaluated at $S=0$ is

$\left.\frac{\mathrm{d} \sigma}{\mathrm{d} S}\right|_{S=0}=-\frac{2}{\sqrt{\pi}}\left(\sigma_{0}-\sigma_{\mathrm{CMC}}\right) K$

Figure 2a provides that an evaluation of $\sigma_{0} / S^{*}$ is the same as evaluating the initial gradient of Eq. (13). Note that the angle is in the second quadrant, while $\sigma_{0} / S^{*}$ is the same as initial gradient, so it is negative of the first derivative of Eq. (13) evaluated at $S=0$.

$\frac{\sigma_{0}}{S^{*}}=-\left.\frac{\mathrm{d} \sigma}{\mathrm{d} S}\right|_{S=0}$

Thus, from the definition of surfactant performance index (Eq. 15), Eq. (16) is proven as Eq. (23).

$\frac{\sigma_{0}}{S^{*}}=\frac{2 \psi}{\sqrt{\pi}}$

\section{References}

Adkins JP, Tanner RS, Udegbunam EO, McInerney MJ, Knapp RM (1992) Microbially enhanced oil recovery from unconsolidated limestone cores. Geomicrobiol J 10:77-86. https://doi. org/10.1080/01490459209377908

Al-Bahry SN, Al-Wahaibi YM, Al-Hinai B et al (2016) Potential in heavy oil biodegradation via enrichment of spore forming bacterial consortia. J Petrol Explor Prod Technol 6(4):787-799. https ://doi.org/10.1007/s13202-016-0228-8

Altiok D, Tokatli F, Harsa S (2006) Kinetic modeling of lactic acid production from whey by Lactobacillus casei (NRRL B-441). J Chem Technol Biotechnol 81:1190-1197. https://doi. org/10.1002/jctb. 1512

Astuti DI et al (2019) Screening and characterization of biosurfactant produced by Pseudoxanthomonas sp. G3 and its applicability for enhanced oil recovery. J Petrol Explor Prod Technol. https://doi. org/10.1007/s13202-019-0619-8

Bao M, Kong X, Jiang G, Wang X, Li X (2009) Laboratory study on activating indigenous microorganisms to enhance oil recovery in Shengli Oilfield. J Petrol Sci Eng 66:42-46. https://doi. org/10.1016/j.petrol.2009.01.001

Baranyi J, Roberts TA (1994) A dynamic approach to predicting bacterial growth in food. Int J Food Microbiol 23:277-294. https://doi. org/10.1016/0168-1605(94)90157-0

Baranyi J, Roberts TA, McClure P (1993) A non-autonomous differential equation to model bacterial growth. Food Microbiol 10:43-59. https://doi.org/10.1006/fmic.1993.1005

Beckmann JW (1926) The action of bacteria on mineral oil. Ind Eng Chem News 4(vember 10):3

Belyaev SS, Borzenkov IA, Nazina TN, Rozanova EP, Glumov IF, Ibatullin RR, Ivanov MV (2004) Use of microorganisms in the biotechnology for the enhancement of oil recovery. Microbiology 
73:590-598. https://doi.org/10.1023/B:MICI.0000044250.21076 $.0 \mathrm{e}$

Birch CPD (1999) A New generalized logistic sigmoid growth equation compared with the richards growth equation. Ann Bot 83:713723. https://doi.org/10.1006/anbo.1999.0877

Bitticaca LAM (2009) (Indonesian) Optimasi Perbandingan Jumlah Inokulum Kultur Campuran Isolat Bakteri Hidrokarbonoklastik dari Lapangan Handil (Kalimantan Timur) untuk Produksi Biosurfaktan. Bachelor thesis, Microbiology Study Program, Institut Teknologi Bandung

Bovill R, Bew J, Cook N, D’Agostino M, Wilkinson N, Baranyi J (2000) Predictions of growth for Listeria monocytogenes and salmonella during fluctuating temperature. Int J Food Microbiol 59:157-165. https://doi.org/10.1016/S0168-1605(00)00292-0

Brody S (1945) Bioenergetics and growth. Reinhold Publishing Corp, New York

Bryant RS (1987) Potential uses of microorganisms in petroleum recovery technology. In: Proceedings of the Oklahoma Academy of Science

Bryant RS (1990) Microbial enhanced oil recovery and compositions therefor. US Patent 4905761 A

Buchanan RL, Whiting RC, Damert WC (1997) When is simple good enough: a comparison of the Gompertz, Baranyi, and three-phase linear models for fitting bacterial growth curves. Food Microbiol 14:313-326. https://doi.org/10.1006/fmic.1997.0125

Cai M, Jimenez N, Kruger M, Guo H, Jun Y, Straaten N, Richnow HH (2015) Potential for aerobic and methanogenic oil biodegradation in a water flooded oil field (Dagang oil field). Fuel 141:143-153. https://doi.org/10.1016/j.fuel.2014.10.035

Cheng M, Lei G, Gao J, Xia T, Wang H (2014) Laboratory experiment, production performance prediction model, and field application of multi-slug microbial enhanced oil recovery. Energy Fuels 28:6655-6665. https://doi.org/10.1021/ef5014083

Corradini MG, Amézquita A, Normand MD, Peleg M (2005) Modeling and predicting non-isothermal microbial growth using general purpose software. Int J Food Microbiol 106:223-228. https://doi.org/10.1016/j.ijfoodmicro.2005.06.014

Daryasafar A, Azad EG, Ghahfarokhi AK, Mousavi SF (2014) Simulation studies on growth and death of microorganisms using the oil-degrading bacteria Petrotoga sp. Chem Eng Technol 37(12):2152-2164. https://doi.org/10.1002/ceat.201400129

Daughtry BJ, Davey KR, King KD (1997) Temperature dependence of growth kinetics of food bacteria. Food Microbiol 14:21-30. https://doi.org/10.1006/fmic.1996.0064

Dominguez SA, Schaffner DW (2007) Development and validation of a mathematical model to describe the growth of Pseudomonas spp. in raw poultry stored under aerobic conditions. Int J Food Microbiol 120:287-295. https://doi.org/10.1016/j.ijfoodmicr o.2007.09.005

Dormand JR, Prince PJ (1980) A familiy of embedded RungeKutta fomulae. J Comp Appl Math 6:19-26. https://doi. org/10.1016/0771-050X(80)90013-3

Ettwig KF, Butler MK, Le Paslier D, Pelletier E, Mangenot S, Kuypers MMM, Schreiber F, Dutilh BE, Zedelius J, de Beer D, Gloerich J, Wessels HJCT, van Alen T, Luesken F, Wu ML, van de Pas-Schoonen KT, Op den Camp, HJM, Janssen-Megens EM, Francoijs K-J, Stunnenberg H, Weissenbach J, Jetten MSM, Strous M (2010) Nitrite-driven anaerobic methane oxidation by oxygenic bacteria. Nature 464:543-548. https://doi.org/10.1038/ nature 08883

Fernandes PL, Rodrigues EM, Paiva FR, Ayupe BAL, McInerney MJ, Totola MR (2016) Biosurfactant, solvents and polymer production by Bacillus subtilis RI4914 and their application for enhanced oil recovery. Fuel 180:551-557. https://doi. org/10.1016/j.fuel.2016.04.080
Fujikawa H, Kai A, Morozumi A (2004) A new logistic model for Escherichia coli growth at constant and dynamic temperatures. Food Microbiol 21:501-509. https://doi.org/10.1016/j. fm.2004.01.007

Fulazzaky M, Astuti DI, Fulazzaky MA (2015) Laboratory simulation of microbial enhanced oil recovery using Geobacillus toebii R-32639 isolated from the Handil reservoir. RSC Adv 5:39083916. https://doi.org/10.1039/C4RA14065F

Gahlawat G, Srivastava AK (2013) Development of a mathematical model for the growth associated polyhydroxybutyrate fermentation by Azohydromonas australica and its use for the design of fed-batch cultivation strategies. Biores Technol 136:98-105. https://doi.org/10.1016/j.biortech.2013.03.023

Ghojavand H, Vahabzadeh F, Shahraki AK (2012) Enhanced oil recovery from low permeability dolomite cores using biosurfactant produced by a Bacillus mojavensis (PTCC 1696) isolated from Masjed-I Soleyman field. J Petrol Sci Eng 81:24-30. https://doi. org/10.1016/j.petrol.2011.12.002

Gompertz B (1825) On the nature of the function expressive of human mortality, and on a new mode to determining the value of life contingencies. Philos Trans R Soc Lond 115:513-585

Gospavic R, Kreyenschmidt J, Bruckner S, Popov V, Haque N (2008) Mathematical modelling for predicting the growth of Pseudomonas spp. in poultry under variable temperature conditions. Int J Food Microbiol 127:290-297. https://doi.org/10.1016/j.ijfoo dmicro.2008.07.022

Goudriaan J, Monteith JL (1990) A mathematical function fro crop growth based on light interception and leaf area expansion. Ann Bot 66:695-701. https://doi.org/10.1093/oxfordjournals.aob. a088084

Goudriaan J, van Laar HH (1994) Modelling potential crop growth process. Kluwer Academic Publishers, Dordrecht

Gougouli M, Angelidis AS, Koutsoumanis K (2008) A study on the kinetic behavior of Listeria monocytogenes in ice cream stored under static and dynamic chilling and freezing conditions. $\mathbf{J}$ Dairy Sci 91:523-530. https://doi.org/10.3168/jds.2007-0255

Gudina EJ, Pereira JFB, Rodrigues LR, Coutinho JAP, Texeira JA (2012) Isolation and study of microorganisms from oil samples for application in microbial enhanced oil recovery. Int Biodeterior Biodegrad 68:56-64. https://doi.org/10.1016/j.ibiod .2012 .01 .001

Hakiki F (2014) A critical review of microbial enhanced oil recovery using artificial sandstone core: a mathematical model. In: 38th annual convention and exhibition of Indonesian Petroleum Association, Jakarta, May 2014, IPA14-SE-119

Hakiki F, Maharsi DA, Marhaendrajana T (2015) Surfactant-polymer coreflood simulation and uncertainty analysis derived from laboratory study. J Eng Technol Sci. https://doi.org/10.5614/j.eng. technol.sci.2015.47.6.9

Hakiki et al (2017) Well and inflow performance relationship for heavy oil reservoir under heating treatment. In: SPE-186187-MS. https ://doi.org/10.2118/186187-MS

Halim AY (2015) Application of microorganisms for enhanced oil recovery. Ph.D. thesis, Center for Energy Resources Engineering, Technical University of Denmark

Halim AY, Fauzi UD, Siregar S, Soewono E, Gunawan AY, Astuti DI, Juli N (2009) Microbial enhanced oil recovery: an investigation of bacteria ability to live and alter crude oil physical characteristics in high pressure condition. Society of Petroleum Engineers. In: SPE 123506. https://doi.org/10.2118/123506-MS

Harner NK, Richardson TL, Thompson KA, Best RJ, Best AS, Trevors JT (2011) Microbial processes in the Athabasca Oil Sands and their potential applications in microbial enhanced oil recovery. J Ind Microbiol Biotechnol 38:1761-1775. https://doi.org/10.1007/ s10295-011-1024-6

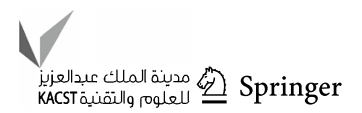


Hartono et al (2017) Revisiting EOR projects in indonesia through integrated study: EOR screening, predictive model, and optimisation. In: SPE-186884-MS. https://doi.org/10.2118/186884-MS

Healy MG, Devine C, Murphy R (1996) Microbial production of biosurfactants. Resour Conserv Recycl 18:41-57. https://doi. org/10.1016/S0921-3449(96)01167-6

Heryani H, Putra MD (2017) Kinetic study and modeling of biosurfactant production using Bacillus sp. Electron J Biotechnol 27:49-54. https://doi.org/10.1016/j.ejbt.2017.03.005

Hosseininoosheri P, Lashgari HR, Sepehrnoori K (2016) A novel method to model and characterize in-situ bio-surfactant production in microbial enhanced oil recovery. Fuel 183:501-5011. https://doi.org/10.1016/j.fuel.2016.06.035

Hossfeld JW (1822) Mathematik für Forstmänner, Okonomeh und Cameralisten. Gotha, 4. Bd. 5. 310

Huang L (2008) Growth kinetics Listeria monocytogenes in broth and beef frankfurters-determination of lag phase duration and exponential growth rate under isothermal conditions. J Food Sci 73:E235-E242 https://doi.org/10.1111/j.1750-3841.2008.00785 .x

Huang L (2013) Optimization of a new mathematical model for bacterial growth. Food Control 32:283-288. https://doi.org/10.1016/j. foodcont.2012.11.019

Ibrahim RW, Ahmad MZ, Al-Janaby HF (2016) Mathematical model for adaptive evolution of populations based on a complex domain. Saudi J Biol Sci 23(1):S45-S49. https://doi. org/10.1016/j.sjbs.2015.09.012

Iraji S, Ayatollahi SJ (2018) Experimental investigation on asphaltene biodegradability using microorganism: cell surface properties' approach. J Petrol Explor Prod Technol. https://doi.org/10.1007/ s13202-018-0537-1

Jadhunandan PP, Morrow NR (1995) Effect of wettability on waterflood recovery for crude-oil/brine/rock systems. Soc Petrol Eng. https://doi.org/10.2118/22597-PA

Janoschek A (1957) Das Reaktions kinetische Grundgesetz und Seire Beziehungen zum Wachstumsund Ertragsgesetz. Statistische Vierteljahresschrift 10:25-37

Janshekar H (1985) Microbial enhanced oil recovery processes. Microb Oil Recov 1:54-84

Jones JE, Walker SJ (1993) Advances in modeling microbial growth. J Ind Micro Biotechnol 12(3-5):200-205

Joshi S, Bharucha C, Desai AJ (2008) Production of biosurfactant and antifungal compound by fermented food isolate Bacillus subtilis 20B. Biores Technol 99:4603-4608. https://doi.org/10.1016/j. biortech.2007.07.030

Juneja VK, Melendres MV, Huang L, Gumudavelli V, Subbiah J, Thippareddi $\mathrm{H}$ (2007) Modeling the effect of temperature on growth of Salmonella in chicken. Food Microbiol 24:328-335. https:// doi.org/10.1016/j.fm.2006.08.004

Juneja VK, Melendres MV, Huang L, Subbiah J, Thippareddi H (2009) Mathematical modeling of growth of Salmonella in rawground beef under isothermal conditions from 10 to $45^{\circ} \mathrm{C}$. Int J Food Microbiol 131:106-111. https://doi.org/10.1016/j.ijfoodmicr o.2009.01.034

Korf VA (1939) Mathematical definition of stand volume growth law. Lesnicka Prace 18:337-339

Kowalewski E, Rueslatten I, Steen KH, Bodtker G, Torsaetor O (2006) Microbial improved oil recovery—bacterial induced wettability and interfacial tension effects on oil production. J Petrol Sci Eng 52:275-286. https://doi.org/10.1016/j.petrol.2006.03.011

Koya PR, Goshu AT (2013) Generalized mathematical model for biological growths Purnachandra. Open J Model Simul 1:42-53. https://doi.org/10.4236/ojmsi.2013.14008

Lagarias JC, Reeds JA, Wright MH, Wright PE (1998) Convergence properties of the Nelder-Mead simplex method in low dimensions. SIAM J Optim 9:112-147. https://doi.org/10.1137/ S1052623496303470

Lal B, Reddy MRV, Agnihotri A, Kumar A, Sarbhai MP, Singh N, Khurana RK, Khazanchi SK, Misra TR (2009) Process for enhanced recovery of crude oil from oil wells using novel microbial consortium. US Patent 7484560:B2

Lazar I, Petrisor IG, Yen TF (2007) Microbial enhanced oil recovery (MEOR). Petrol Sci Technol 25:1353-1366. https://doi. org/10.1080/10916460701287714

Levakovic A (1935) Analytical Form of Growth Laws. Glasnik za Sumske Pokuse (Zagreb) 4:189-282

Lotka AJ (1910) Contribution to the theory of periodic reaction. J Phys Chem 14:271-274

Lucas N, Bienaime C, Belloy C, Queneudec M, Silvestre F, NavaSaucedo J-E (2008) Polymer biodegradation: mechanisms and estimation techniques-a review. Chemosphere 73:429-442. https://doi.org/10.1016/j.chemosphere.2008.06.064

Lundqvist B (1957) On the height growth in cultivated stands of pine and spruce in northern Sweden. Meddelanden Fran Statens Skogsforsknings-institut 47:1-64

Manzoni S, Pineiro G, Jackson R, Jobbágye E, Kim J, Porporatoab A (2012) Analytical models of soil and litter decomposition: solutions for mass loss and time-dependent decay rates. Soil Biol Biochem 50:66-76. https://doi.org/10.1016/j.soilbio.2012.02.029

McDill ME, Amateis RL (1992) Measuring forest site quality using the parameters of a dimensionally compatible height growth function. For Sci 38:409-429

McInerney MJ, Nagle DP, Knapp RM (2005) Microbially enhanced oil recovery: past, present, and future. Petrol Microbiol. https://doi. org/10.1128/9781555817589.ch11

Mohammed MJ, Ibrahim RW, Ahmad MZ (2017) Periodicity computation of generalized mathematical biology problems involving delay differential equations. Saudi J Biol Sci 24(3):737-740. https://doi.org/10.1016/j.sjbs.2017.01.050

Ohms DS, McLeod JD, Graff CJ, Frampton H, Morgan J, Cheung SK, Yancey KE, Chang KT (2009) Incremental oil success from waterflood sweep improvement in Alaska. Society of Petroleum Engineers. In: SPE 121761-MS. https://doi.org/10.2118/12176 1-MS

Okeke T, Lane RH (2012) Simulation and economic screening of improved-conformance oil recovery by polymer flooding and a thermally activated deep diverting gel. Society of Petroleum Engineers. In: SPE 153740-MS. https://doi.org/10.2118/15374 0-MS

Patel J, Borgohain S, Kumar M, Rangarajan V, Somasundaran P, Sen R (2015) Recent developments in microbial enhanced oil recovery. Renew Sustain Energy Rev. https://doi.org/10.1016/j. rser.2015.07.135

Pinilla L, Torres R, Ortiz C (2011) Bioethanol production in batch mode by a native strain of Zymomonas mobilis. World J Microbiol Biotechnol 27:2521-2528. https://doi.org/10.1007/s1127 4-011-0721-7

Pornsunthorntawee O, Arttaweeporn N, Paisanjit S, Somboonthanate P, Abe M, Rujiravanit R, Chavadej S (2008) Isolation and comparison of biosurfactants produced by Bacillus subtilis PT2 and Pseudomonas aeruginosa SP4 for microbial surfactantenhanced oil recovery. Biochem Eng J 42:172-179. https://doi. org/10.1016/j.bej.2008.06.016

Primeia S (2008) (Indonesian) Optimasi Sumber Nitrogen Inorganik pada Produksi Biosurfaktan oleh Bakteri Hidrokarbonoklastik dari Lapangan Handil, Kalimantan Timur. Bachelor Thesis, Microbiology Study Program, Institut Teknologi Bandung

Pruitt KM, Kamau DN (1993) Mathematical models of bacterial growth, inhibition and death under combined stress conditions. J Ind Microbiol Biotechnol 12(3-5):221-231. https:// doi.org/10.1007/BF01584194 
Purwasena IA (2006) (Indonesian) Isolasi dan Karakterisasi Bakteri Hidrokarbonoklastik dari Reservoir Minyak Bumi Kalimantan yang Berpotensi Bagi Penerapan Teknologi MEOR (Microbial enhanced oil recovery). Thesis, Microbiology Study Program, Institut Teknologi Bandung

Purwasena IA, Sugai Y, Sasaki K (2014) Estimation of the potential of an anaerobic thermophilic oil-degrading bacterium as a candidate for MEOR. J Pet Explor Prod Technol 4(2):189-200. https://doi.org/10.1007/s13202-013-0095-5

Raghoebarsing AA, Pol A, van de Pas-Schoonen KT, Smolders AJP, Ettwig KF, Rijpstra W, Schouten IC, Damsté S, Op JSS, den Camp HJM, Jetten MSM, Strous M (2006) A microbial consortium couples anaerobic methane oxidation to denitrification. Nature 440:918-921. https://doi.org/10.1038/nature04617

Raiders RA, Knapp RM, McInerney MJ (1989) Microbial selective plugging and enhanced oil recovery. J Ind Microbiol Biotechnol 4(3):215-229. https://doi.org/10.1007/BF01574079

Richards FJ (1959) A flexible growth function for empirical use. J Exp Bot 10:290-300. https://doi.org/10.1093/jxb/10.2.290

Sager G (1984) Seasonally modified forms of the revised Janoschek growth function, vol 130. Gegenbaurs morphologisches Jahrbuch, Leipzig, pp 659-669

Salager J et al (2000) Partitioning of ethoxylated octylphenol surfactants in microemulsion-oil-water systems: influence of temperature and relation between partitioning coefficient and physicochemical formulation. Langmuir 16(13):5534-5539. https://doi.org/10.1021/la9905517

Salih M, Mytilinaios I, Schofield HK, Lambert RJW (2012) Modelling of bacterial growth with shifts in temperature using automated methods with Listeria monocytogenes and Pseudomonas aeruginosa as examples. Int J Food Microbiol 155:29-35. https ://doi.org/10.1016/j.ijfoodmicro.2012.01.011

Schnute JC (1981) A versatile growth model with statistically stable parameters. Can J Fish Aquat Sci 38:1128-1140. https://doi. org/10.1139/f81-153

Scott MJ, Jones MN (2000) The biodegradation of surfactants in the environment. Biochimica et Biophysica Acta (BBA) Biomembranes 1508:235-251. https://doi.org/10.1016/S0304 $-4157(00) 00013-7$

Sen R (2008) Biotechnology in petroleum recovery: the microbial EOR. Prog Energy Combust Sci 34:714-724. https://doi. org/10.1016/j.pecs.2008.05.001

Sloboda B (1971) Investigation of growth processes using first-order differential equations. Mitteilungen der Baden-Württembergischen Foustlichen Versuchs und Forschungsanstalt, Heft, p 32

Song HS, Liu C (2015) Dynamic metabolic modeling of denitrifying bacterial growth: the cybernetic approach. Ind Eng Chem Res 54(42):10221-10227. https://doi.org/10.1021/acs.iecr.5b01615

Stannard CJ, Williams AP, Gibbs PA (1985) Temperature/growth relationship for psychotropic food-spoilage bacteria. Food Microbiol 2:115-122

Sugai Y, Purwasena IA, Sasaki K, Fujiwara K (2010) Evaluation of the potential of microbial conversion process of $\mathrm{CO}_{2}$ into $\mathrm{CH}_{4}$ by investigating the microorganisms in high $\mathrm{CO}_{2}$ content oilfield. Soc Petrol Eng. https://doi.org/10.2118/137568-MS

Swinnen IAM, Bernaerts K, Dens EJJ, Geeraerd AH, Van Impe JF (2004) Predictive modelling of the microbial lag phase: a review. Int J Food Microbiol 94:137-159. https://doi.org/10.1016/j.ijfoo dmicro.2004.01.006

Theys TE, Geeraerd AH, Verhulst A, Poot K, Van Bree I, Devlieghere F, Moldenaers P, Wilson D, Brocklehurst T, Van Impe JF (2008) Effect of $\mathrm{pH}$, water activity, and gel micro-structure, including oxygen profiles and rheological characterization, on the growth kinetics of Salmonella typhimurium. Int J Food Microbiol 128:67-77. https://doi.org/10.1016/j.ijfoodmicro.2008.06.031
Tianyuan W, Li Y, Jianlong X, Yuandong M, Wei L, Ting M, Xiangyang W, Lin W (2018) A mathematical model for microbial enhanced oil recovery using biopolymer-producing microorganism. Fuel 216:589-595. https://doi.org/10.1016/j.fuel.2017.12.058

Torrealba VA, Johns RT (2017) Coupled interfacial tension and phase behavior model based on micellar curvatures. Langmuir 33(47):13604-13614. https://doi.org/10.1021/acs.langm uir.7b03372

Udegbunam EO, Adkins JP, Knapp RM, McInerney MJ, Tanner RS (1991) Assessing the effects of microbial metabolism and metabolites on reservoir pore structure. Society of Petroleum Engineers. In: SPE 22846-MS. https://doi.org/10.2118/22846-MS

Varjani SJ, Upasani VN (2016) Core flood study for enhanced oil recovery through ex-situ bioaugmentation with thermo- and halo-tolerant rhamnolipid produced by Pseudomonas aeruginosa NCIM 5514. Biores Technol 220:175-182. https://doi. org/10.1016/j.biortech.2016.08.060

Verhulst PF (1838) Notice Sur la loi que la Population Suit Dans Son Accroissement. Correspondence Mathematique et Physique $10: 113-121$

Veshareh MJ et al (2018) Isolation and screening of Bacillus subtilis MJ01 for MEOR application: biosurfactant characterization, production optimization and wetting effect on carbonate surfaces. J Petrol Explor Prod Technol. https://doi.org/10.1007/s1320 2-018-0457-0

von Bertalanffy L (1957) Quantitative laws in metabolism and growth. Q Rev Biol 32:217-231

Weibull WA (1951) Satistical distribution function of wide applicability. J Appl Mech 18:291-297

Xu Y, Lu M (2011) Microbially enhanced oil recovery at simulated reservoir conditions by use of engineered bacteria. J Petrol Sci Eng 78:233-238. https://doi.org/10.1016/j.petrol.2011.06.005

Yakimov MM, Amro MM, Bock M, Boseker K, Fredrickson HL, Kessel DG, Timmis KN (1997) The potential of Bacillus licheniformis strains for in situ enhanced oil recovery. J Petrol Sci Eng 18:147-160. https://doi.org/10.1016/S0920-4105(97)00015-6

Yang JS, Tantayotai RE, Scow P, Yuan KM, H. L., and Hristova K (2011) Mathematical model of Chlorella minutissima UTEX2341 growth and lipid production under photoheterotrophic fermentation conditions. Biores Technol 102:3077-3082. https://doi. org/10.1016/j.biortech.2010.10.049

Yin X, Kropff MJ, McLaren G, Visperas RM (1995) A nonlinear model for crop development as a function of temperature. Agric For Meteorol 77:1-16. https://doi.org/10.1016/0168-1923(95)02236 -Q

Yin X, Goudriaan J, Lantinga EA, Vos J, Spiertz HJ (2003) A Flexible sigmoid function of determinate growth. Ann Bot 91:361-371. https://doi.org/10.1093/aob/mcg029

Yoshida S (1981) Fundamentals of rice crop science. International Rice Research Institute, Los Banos

Zhao F, Li P, Guo C, Shi RJ, Zhang Y (2018) Bioaugmentation of oil reservoir indigenous Pseudomonas aeruginosa to enhance oil recovery through in-situ biosurfactant production without air injection. Biores Technol 251:295-302. https://doi.org/10.1016/j. biortech.2017.12.057

Zheng X, Li D (2016) Interaction of Acidithiobacillus ferrooxidans, Rhizobium phaseoli and Rhodotorula sp. in bioleaching process based on Lotka-Volterra model. Electronic J Biotechnol 26:9097. https://doi.org/10.1016/j.ejbt.2016.06.004

Zheng C, Yu L, Huang L, Xiu J, Huang Z (2012) Investigation of a hydrocarbon-degrading strain, Rhodococcus ruber Z25, for the potential of microbial enhanced oil recovery. J Petrol Sci Eng. https://doi.org/10.1016/j.petrol.2011.12.019

ZoBell CE (1947a) Bacterial release of oil from oil-bearing materials, part I. World Oil 126(13):36-47 
ZoBell CE (1947b) Bacterial release of oil from oil-bearing materials, part II. World Oil 127(1):35-41

Zwietering MH, de Wit JC, Cuppers HG, A. M, van 't Riet K (1994)

Modeling of bacterial growth with shifts in temperature. Appl Environ Microbiol 60:204-213
Publisher's Note Springer Nature remains neutral with regard to jurisdictional claims in published maps and institutional affiliations. 